\title{
Investigation of elemental mercury removal from the coal-fired boiler flue gas over MIL101-Cr
}

Lu Dong ${ }^{1,2}$, Yaji Huang ${ }^{1 *}$, Lingqin Liu ${ }^{1}$, Changqi Liu ${ }^{1}$, Ligang $X u^{1}$, Jianrui Zha ${ }^{1}$, Hao Chen ${ }^{1}$,

\author{
Hao $\operatorname{Liu}^{2 *}$
}

${ }^{1}$ Key Laboratory of Energy Thermal Conversion and Control of Ministry of Education, School of Energy and Environment, Southeast University, Nanjing 210096, China

${ }^{2}$ Faculty of Engineering, University of Nottingham, University Park, Nottingham, NG7 2RD,

England, UK

\section{Corresponding authors}

*Yaji Huang, heyyj@seu.edu.cn

*Hao Liu, liu.hao@nottingham.ac.uk

\begin{abstract}
In this work, the MIL101-Cr sorbent with a large BET surface area was prepared and used to remove $\mathrm{Hg}^{0}$ from the simulated coal-fired boiler flue gas. The chemical and physical properties of the prepared sorbent were characterized by X-ray diffraction (XRD), Brunauer-Emmett-Teller (BET) and X-ray photoelectron spectroscopy (XPS). A range of experiments was conducted in a fixed-bed reactor to investigate the effects of reaction temperature, $\mathrm{Hg}^{0}$ inlet concentration, gas hourly space velocity
\end{abstract}


(GHSV) and flue gas composition on the $\mathrm{Hg}^{0}$ removal for the prepared sorbent. The mechanisms and kinetics of the $\mathrm{Hg}^{0}$ adsorption were also studied. The results showed that the MIL101-Cr sorbent achieved the $\mathrm{Hg}^{0}$ removal efficiency of more than $85 \%$ for $4 \mathrm{~h}$ at $200{ }^{\circ} \mathrm{C}$ under the condition of a relatively high $\mathrm{Hg}^{0}$ inlet concentration $\left(203 \mu \mathrm{g} / \mathrm{m}^{3}\right)$ and GHSV $\left(8 \times 10^{5} \mathrm{~h}^{-1}\right)$. The $\mathrm{O}_{2}$ in the flue gas was found to be beneficial to $\mathrm{Hg}^{0}$ removal. The $\mathrm{NO}$ in the flue gas favoured $\mathrm{Hg}^{0}$ removal both in the presence and absence of $\mathrm{O}_{2}$. The $\mathrm{SO}_{2}$ in the flue gas notably inhibited $\mathrm{Hg}^{0}$ adsorption in the absence of $\mathrm{O}_{2}$, whereas a low concentration of $\mathrm{SO}_{2}$ slightly inhibited $\mathrm{Hg}^{0}$ removal in the presence of $\mathrm{O}_{2}$. However, high concentrations of $\mathrm{SO}_{2}$ in the flue gas still significantly weakend $\mathrm{Hg}^{0}$ removal ability even in the presence of $\mathrm{O}_{2}$ due to the competitive adsorption of $\mathrm{SO}_{2}$ with $\mathrm{Hg}^{0}$ on the sorbent and the sulfation of the sorbent. A simultaneous presence of $\mathrm{O}_{2}$ and $\mathrm{NO}$ in the flue gas could overcome the adverse impact of $\mathrm{SO}_{2}$ on $\mathrm{Hg}^{0}$ adsorption. The $\mathrm{H}_{2} \mathrm{O}$ has little influence on $\mathrm{Hg}^{0}$ removal due to the competitive adsorption. The XPS analysis indicated that the surface $\mathrm{Cr}^{3+}$, oxygen species and $\mathrm{C}=\mathrm{O}$ group in MIL101-Cr acted as the active adsorption/oxidation sites for $\mathrm{Hg}^{0}$. $\mathrm{The}^{\mathrm{H}} \mathrm{Hg}^{0}$ removal by MIL101-Cr belonged to chemisorption and could be described by the pseudo-second-order model. The equilibrium adsorption capacity calculated for the sorbent amounted to $25656 \mu \mathrm{g} / \mathrm{g}$ at $200{ }^{\circ} \mathrm{C}$, which indicated that MIL101-Cr could be used as a promising sorbent to remove $\mathrm{Hg}^{0}$ from the coal-fired boiler flue gas.

Keywords: MIL101-Cr; Elemental Mercury; Flue gas; Chemical Adsorption 


\section{Introduction}

Over the recent decades, mercury emissions from coal-fired boilers have attracted worldwide attention due to its extreme toxicity, high volatility, and strong bioaccumulation in the ecosystem ${ }^{1-3}$. Mercury is treated as a hazardous and toxic pollutant according to Title III of the 1990 Clean Air Act Amendments (CAAA) in the United States ${ }^{4}$. Coal combustion is considered as the main anthropogenic source of mercury release on the account of the increasing world energy demands and the continual use of coal for power generation in many countries such as China and India ${ }^{5,6}$. The mercury emission of new coal-fired power plants has been limited by the United States Environment Protection Agency (EPA) to $5.9-54.5 \mathrm{~g} / \mathrm{GWh}^{7}$. Emission standards for air pollutants from coal-fired power plants in China has limited the mercury emission to $0.03 \mathrm{mg} / \mathrm{m}^{3}{ }^{8}$. Moreover, the Minamata Convention on Mercury for mercury restriction was signed by 140 countries in 2013 and came in to effect in $2017^{9}$.

There are generally existed three states of mercury species in coal combustion flue gas: the oxidized mercury $\left(\mathrm{Hg}^{2+}\right)$, the elemental mercury $\left(\mathrm{Hg}^{0}\right)$, and the particulate-bound mercury $\left(\mathrm{Hg}^{\mathrm{p}}\right) . \mathrm{Hg}^{2+}$ and $\mathrm{Hg}^{\mathrm{p}}$ can be easily captured by the wet flue gas desulfurization (WFGD) system and particulate control devices (PCDs), respectively, both of which are now the essential equipment of a modern coal-fired power plant. However, $\mathrm{Hg}^{0}$ is hard to be captured by the existing air pollution control devices (APCDs) due to its high volatility and insolubility ${ }^{10}$. Therefore, the key challenge to control mercury emissions from coal-fired power plants is how to effectively remove $\mathrm{Hg}^{0}$ from the coal-fired boiler flue gas ${ }^{11}$.

Both adsorption and oxidation of $\mathrm{Hg}^{0}$ are deemed as the two common methods for its removal. The adsorption of $\mathrm{Hg}^{0}$ by use of mercury removal adsorbents has been widely applied in the lab and industrial scales. In this process, the sorbents are injected into the coal-fired flue gas to adsorb $\mathrm{Hg}^{0}$ 
directly and subsequently are removed by the APCDs. Among the adsorption-based technologies, the activated carbon injection (ACI) has been commercially used for mercury removal since $2001{ }^{12,13}$. Activated carbons (ACs) with large specific surface areas and rich oxygen groups on the surface favour the mercury removal. It was found that the mercury removal ability of an AC could be greatly enhanced via the modification with halogen ${ }^{10}$, sulfur ${ }^{14}$, metal oxides ${ }^{15}$, and so on. However, the use of AC could adversely impede the commercial application of the fly ash due to the increasing of carbon in the ash ${ }^{16}$. To avoid such issue, many investigations on the development of non-carbon based sorbents, including mineral sorbents ${ }^{17,18}$, metal oxides sorbents ${ }^{19}$, and fly ash based sorbents ${ }^{20,21}$ have been carried out in recent years. The sorbents with high specific surface areas that contribute to physisorption of $\mathrm{Hg}^{0}$ and abundant chemical active sites that are in favor of chemisorption and oxidation of $\mathrm{Hg}^{0}$ need to be developed ${ }^{22}$. Metal-organic frameworks (MOFs) with the hybrid inorganic-organic microporous crystalline, which are self-assembled straight-forwardly from metal ions with organic linkers via coordination bonds ${ }^{23,24}$, have recently attracted increasing interests due to their fascinating structures and unique properties, including high surface area, exceptional thermal stability, developed pore structures, and been applied to wastewater purification ${ }^{25}$, lithium-ion battery anode $^{26}$, and gas storage ${ }^{27}$. A number of studies have investigated the mercury removal performance over various MOFs in the recent years such as the MIL101-Cr ${ }^{4}$, the $\mathrm{Br}$-modified UiO- $66^{28}$, the $\mathrm{Cu}-$ $\mathrm{BTC}^{29}$, and the manganese-cerium loaded MOFs ${ }^{30}$. All of these MOF based mercury sorbents have exhibited good $\mathrm{Hg}^{0}$ performance and potential to be used as substitutes for AC sorbents. Among these MOF sorbents, the MIL101-Cr (chromium terephthalate) is an attractive candidate for the mercury adsorption due to its extra-high specific surface area (approximately $2500 \mathrm{~m}^{2} / \mathrm{g}$ ), good thermal stability 
(decomposed more than $300{ }^{\circ} \mathrm{C}$ ) and the chemical activity (the presence of Cr). Several studies have shown that Cr-containing catalysts exhibit superior catalytic activity. Chromium oxide was proved to be very active for $\mathrm{Hg}^{0}$ oxidation ${ }^{31,32}$. Chen et al. have found that the introduction of $\mathrm{Cr}$ into $\mathrm{MnOx}-$ $\mathrm{TiO}_{2}$ sorbents could significantly enhance their $\mathrm{Hg}^{0}$ removal performance in the absence and presence of $\mathrm{SO}_{2}{ }^{32}$. Zhao et al. studied the $\mathrm{Hg}^{0}$ removal from the sintering flue gas of iron and steel over MIL101$\mathrm{Cr}$ and the results showed that $\mathrm{Hg}^{0}$ removal efficiency could reach about $88 \%$ at $250{ }^{\circ} \mathrm{C}$ and $\mathrm{Cr}^{3+}$ on the surface could effectively oxidize $\mathrm{Hg}^{0}{ }^{4}$. However, the oxygen and moisture contents in the sintering flue gas are always higher than those in the coal-fired flue gas ${ }^{4}$, and the $\mathrm{SO}_{2}$ concentration varies widely in the sintering flue gas ${ }^{33}$. The temperature of the sintering gas is in the range of $120-180{ }^{\circ} \mathrm{C}$ ${ }^{29}$, which is lower than that in the coal-fired flue gas at the down-stream of the SCR device (150-350 $\left.{ }^{\circ} \mathrm{C}\right){ }^{34}$. In addition, Zhao et al. ${ }^{4}$ only investigated the effect of $\mathrm{O}_{2}$ in the flue gas on the $\mathrm{Hg}^{0}$ removal performance of MIL101-Cr. Both the sintering flue gas and the coal-fired boiler flue gas contain other active gaseous components such as $\mathrm{NO}, \mathrm{SO}_{2}$, and $\mathrm{H}_{2} \mathrm{O}$ and the presence of these gaseous components in the flue gas can significantly affect the $\mathrm{Hg}^{0}$ removal performance of MIL101-Cr. Hence, to fully assess the $\mathrm{Hg}^{0}$ removal performance of MIL101-Cr, the investigation of the $\mathrm{Hg}^{0}$ removal performance must be conducted with an atmosphere containing all of the important active flue gas components $\left(\mathrm{O}_{2}\right.$, $\mathrm{NO}, \mathrm{SO}_{2}$, and $\mathrm{H}_{2} \mathrm{O}$ ).

In current work, the MIL101-Cr sorbent was prepared and used to remove $\mathrm{Hg}^{0}$ from the simulated coal-fired boiler flue gas on a fixed-bed reactor. The effects of adsorption temperature, the $\mathrm{Hg}^{0}$ inlet concentration, the gas hourly space velocity (GHSV) and the individual flue gas components on the $\mathrm{Hg}^{0}$ removal performance over the prepared MIL101-Cr were investigated systematically. The 
mercury removal mechanisms and adsorption kinetics were also studied in order to further understand the $\mathrm{Hg}^{0}$ adsorption over the MIL101-Cr sorbent, which would help to develop the promising $\mathrm{Hg}^{0}$ removal sorbents for coal-fired power plants.

\section{Experiment and computational method}

\subsection{Experimental section}

\subsubsection{Sorbents preparation}

The MIL101-Cr sorbent was prepared following the well estabilished hydrothermal method ${ }^{4,35}$. Briefly, $\mathrm{Cr}\left(\mathrm{NO}_{3}\right)_{3} \cdot 9 \mathrm{H}_{2} \mathrm{O}(16 \mathrm{mmol})$ and terephthalic acid $(16 \mathrm{mmol})$ were dissolved in deionized water $(100 \mathrm{~mL})$ under the vigorous stirring contdition to form a clear solution. Then the solution was transferred into a $200 \mathrm{ml}$ Teflon-lined stainless-steel autoclave and heated at $220^{\circ} \mathrm{C}$ for $18 \mathrm{~h}$ without stirring. After cooling to room temperature, the obtained green solid was centrifuged and washed with DMF and ethyl alcohol several times at $60{ }^{\circ} \mathrm{C}$, and then dried in an oven at $150{ }^{\circ} \mathrm{C}$ overnight.

The commercial AC was purchased from Miaoyuan Material Co. (Gongyi, China). The commercial $\mathrm{Br}-\mathrm{AC}$ was synthesized by impregniation method using $\mathrm{NH}_{4} \mathrm{Br}$ solution. $10 \mathrm{~g}$ of the commercial $\mathrm{AC}$ were dispersed to the $1 \mathrm{wt} \% \mathrm{NH}_{4} \mathrm{Br}$ solution with $12 \mathrm{~h}$ stirring. Then the $\mathrm{NH}_{4} \mathrm{Br}-\mathrm{impregnated}$ commercial $\mathrm{AC}$ was dried in a thermostat drying oven at $110^{\circ} \mathrm{C}$ for $6 \mathrm{~h}$ and the commercial $\mathrm{Br}-\mathrm{AC}$ was prepared finally.

\subsubsection{Characterization}

The powder X-ray diffraction (XRD) measurements were performed on a XD-3 X-ray diffractometer with $\mathrm{Cu}-\mathrm{K} \alpha$ radiation and operating at $50 \mathrm{kV}$ and $200 \mathrm{~mA}$ (X'Pert PRO MPD, Nederland). The $\mathrm{N}_{2}$ specific BET surface area was measured by $\mathrm{N}_{2}$ adsorption in a constant volume adsorption apparatus 
analyzer (Gold APP, China). The XPS measurements were made on a K- $\alpha$ spectrometer (Thermo ESCALAB 250XI, US) at room temperature under ultra-high vacuum. All binding energies of the samples were calibrated using the reference carbon $(\mathrm{C} 1 \mathrm{~s})$ peak at $284.8 \mathrm{eV}$.

\subsubsection{Experimental method}

The $\mathrm{Hg}^{0}$ removal tests were carried out in a fixed-bed quartz tube reactor system, as described schematically in Fig. 1. The experiment system mainly consisted of simulated flue gas supply system, mercury vapour generator, reaction temperature control system, adsorption reactor and $\mathrm{Hg}^{0}$ online analyzer. The simulated flue gas, including the carrier gas $\left(\mathrm{N}_{2}\right)$ for the mercury vapour, had a total flow rate of $1000 \mathrm{ml} / \mathrm{min}$ and was composed of $\mathrm{N}_{2}, \mathrm{O}_{2}, \mathrm{SO}_{2}, \mathrm{NO}$ and $\mathrm{H}_{2} \mathrm{O}$. A flow $300 \mathrm{ml} / \mathrm{min}$ of $\mathrm{N}_{2}$ was used as the carrier gas to convey the mercury vapour from a mercury permeation device, which was sealed in a U-shaped quartz tube and placed in a water bath to introduce a specified $\mathrm{Hg}^{0}$

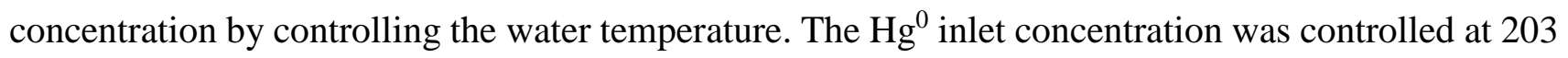
$\mu \mathrm{g} / \mathrm{m}^{3}$ with the baseline tests and was altered to 132 and $74 \mu \mathrm{g} / \mathrm{m}^{3}$ for other specific experimental conditions. As shown in Fig. 1, the $\mathrm{Hg}^{0}$ carried by the carrier gas $\left(\mathrm{N}_{2}\right)$ and the flows of different gaseous components of the simulated flue gas were premixed before passing through the fixed-bed reactor. The concentration of each gaseous component in the simulated flue gas was calculated by dividing the flow rate of the gaseous component with the total flue gas flow rate after the mixing chamber. The adsorption tests were conducted by packing $50 \mathrm{mg}$ sorbents (with particles of 40-60 meshes) into a quartz glass tube reactor (i.d. $8 \mathrm{~mm}$ ) that was placed in a temperature-controlled furnace. The GHSV under the baseline test condition was about $8 \times 10^{5} \mathrm{~h}^{-1}$. The GHSV was set at different values by using various amounts of sorbents $(25 \mathrm{mg}, 100 \mathrm{mg}$ and $200 \mathrm{mg}$ ) for better understanding the influence of 
GHSV on the $\mathrm{Hg}^{0}$ removal performance. The $\mathrm{Hg}^{0}$ concentration of the outlet gas was detected by an online continuous vapour-mercury analyzer with the accuracy of $0.1 \mathrm{ug} / \mathrm{m}^{3}$ and the detection limit of $0.1 \mathrm{ug} / \mathrm{m}^{3}$ (VM3000, Mercury Instruments, Germany). The vent gas was purified using activated carbon and sodium hydroxide solution to avoid air pollution. At the beginning of each test, the gas containing $\mathrm{Hg}^{0}$ was first passed through a bypass quartz tube without adsorbents to stabilize the mercury concentration. When the concentration of $\mathrm{Hg}^{0}$ fluctuated within $\pm 5 \%$ for more than $30 \mathrm{~min}$, the gas was diverted to the reactor tuber which contained the sorbents. All the gas flow lines were kept at about $110^{\circ} \mathrm{C}$ by use of heating tapes to avoid the condensation of gaseous $\mathrm{Hg}^{0}$ and water vapour. The impingers containing $\mathrm{NaOH}$ aqueous solution and silicone gel were located before the mercury analyzer inlet to avoid the corrosion of the analyzer caused by the acid gases and water vapour. In order to investigate the $\mathrm{Hg}^{0}$ adsorption and oxidation behavior during the $\mathrm{Hg}^{0}$ removal process over MIL101-Cr, a mercury speciation conversion system which included two impringers contained either a $\mathrm{KCl}$ solution (side I) or a $10 \% \mathrm{SnCl}_{2} / \mathrm{HCl}$ solution (side II) was used and placed between the $\mathrm{NaOH}$ impringer and the silicone gel impringer (Fig. 1). When the simulated flue gas passed through side I, the $\mathrm{Hg}^{2+}\left(\mathrm{Hg}_{\text {out }}^{2+}\right)$ was captured by $\mathrm{KCl}$ solution and only the $\mathrm{Hg}^{0}\left(\mathrm{Hg}_{\text {out }}^{0}\right)$ was measured by the VM3000. When the flue gas passed through side II, gaseous $\mathrm{Hg}^{2+}$ was reduced to $\mathrm{Hg}^{0}$, and the total mercury concentration $\left(H g_{\text {out }}^{T}=H g_{\text {out }}^{0}+H g_{\text {out }}^{2+}\right)$ was determined by the mercury analyzer (VM3000). The total $\mathrm{Hg}^{0}$ removal efficiency $\left(\mathrm{E}_{\mathrm{T}}\right), \mathrm{Hg}^{0}$ adsorption efficiency $\left(\mathrm{E}_{\mathrm{ads}}\right)$ and the $\mathrm{Hg}^{0}$ oxidation efficiency $\left(\mathrm{E}_{\text {oxi }}\right)$ were calculated using following equations (1-3):

$$
\mathrm{E}_{\mathrm{T}}=\frac{\sum_{0}^{t} H g_{\text {in }}^{0}-\sum_{0}^{t} H g_{\text {out }}^{0}}{\sum_{0}^{t} H g_{\text {in }}^{0}} \times 100 \%
$$




$$
\begin{aligned}
\mathrm{E}_{\mathrm{ads}}= & \frac{\sum_{0}^{t} H g_{\text {in }}^{0}-\sum_{0}^{t} H g_{\text {out }}^{\mathrm{T}}}{\sum_{0}^{t} H g_{\text {in }}^{0}} \times 100 \% \\
\mathrm{E}_{\text {oxi }} & =\frac{\sum_{0}^{t} H g_{\text {out }}^{\mathrm{T}}-\sum_{0}^{t} H g_{\text {out }}^{0}}{\sum_{0}^{t} H g_{\text {in }}^{0}} \times 100 \%
\end{aligned}
$$

where $H g_{\text {in }}^{0}$ donates the inlet $\mathrm{Hg}^{0}$ concentration $\left(\mu \mathrm{g} / \mathrm{m}^{3}\right), \mathrm{Hg}_{\text {out }}^{0}$ donates the outlet $\mathrm{Hg}^{0}$ concentration $\left(\mu \mathrm{g} / \mathrm{m}^{3}\right)$, and $H g_{\text {out }}^{\mathrm{T}}$ donates the outlet total mercury concentration $\left(\mu \mathrm{g} / \mathrm{m}^{3}\right) . \mathrm{t}$ donates the adsorption time (min).

The accumulative $\mathrm{Hg}^{0}$ adsorption capacity $\mathrm{q}_{\mathrm{t}}(\mathrm{ug} / \mathrm{g})$ could be calculated by the following equation:

$$
\mathrm{q}_{\mathrm{t}}=\frac{1}{\mathrm{~m}} \int_{0}^{t}\left(H g_{\text {in }}^{0}-H g_{\text {out }}^{0}\right) \times \mathrm{Qdt}
$$

where Q represents the total gas flow rate $\left(\mathrm{m}^{3} / \mathrm{min}\right)$ and $\mathrm{m}$ represents the sorbent mass $(\mathrm{g})$.

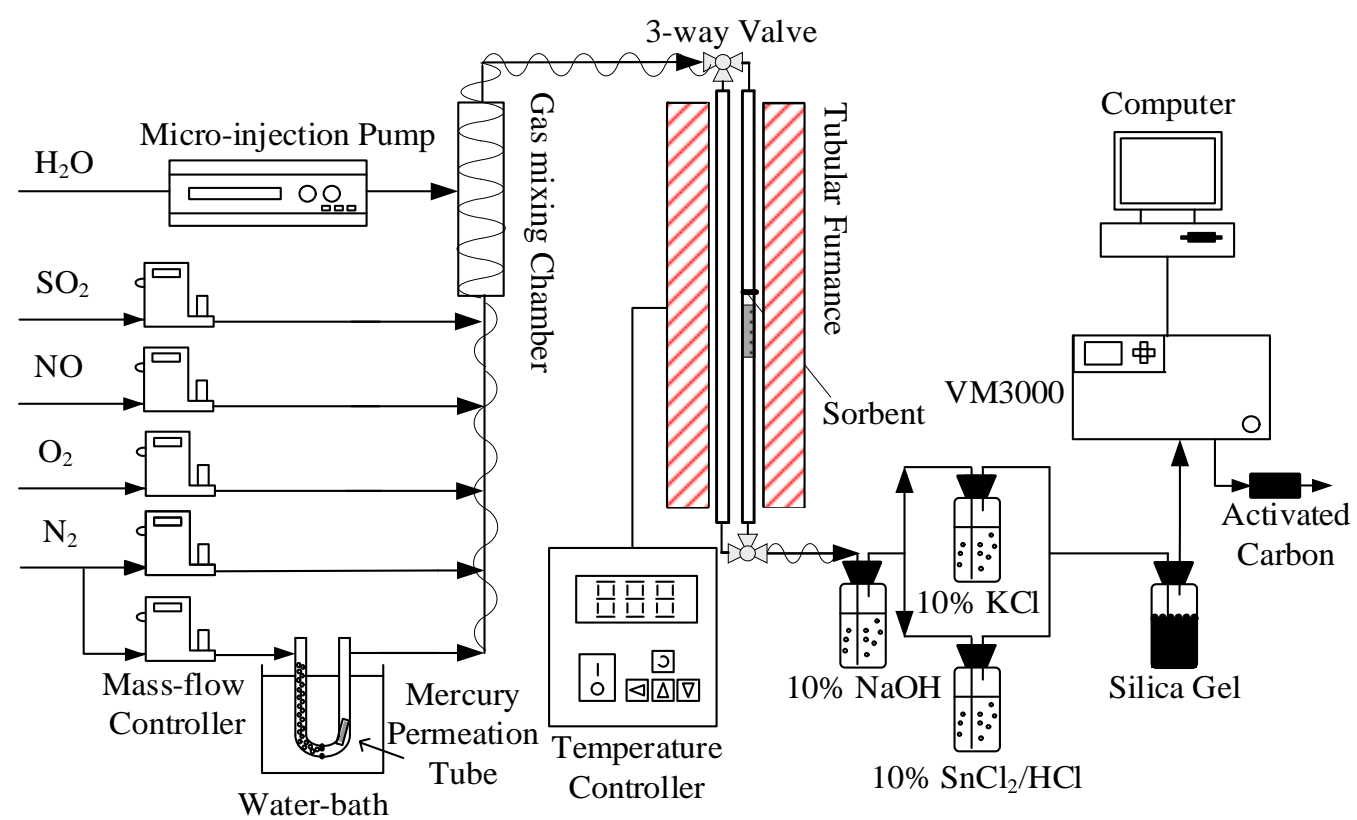

Fig. 1 Schematic diagram of the fixed-bed reactor system. 


\section{Results and discussion}

\subsection{Sample characterization}

The XRD patterns of the prepared MIL101-Cr sample are shown in Fig. 2. The characteristic peaks at $5.16^{\circ}, 8.50^{\circ}, 5.62^{\circ}, 5.92^{\circ}$ and $9.12^{\circ}$ are consistent with the peak locations and relative intensities reported for MIL101-Cr ${ }^{36}$, suggesting the successful preparation of the MIL101-Cr sample.

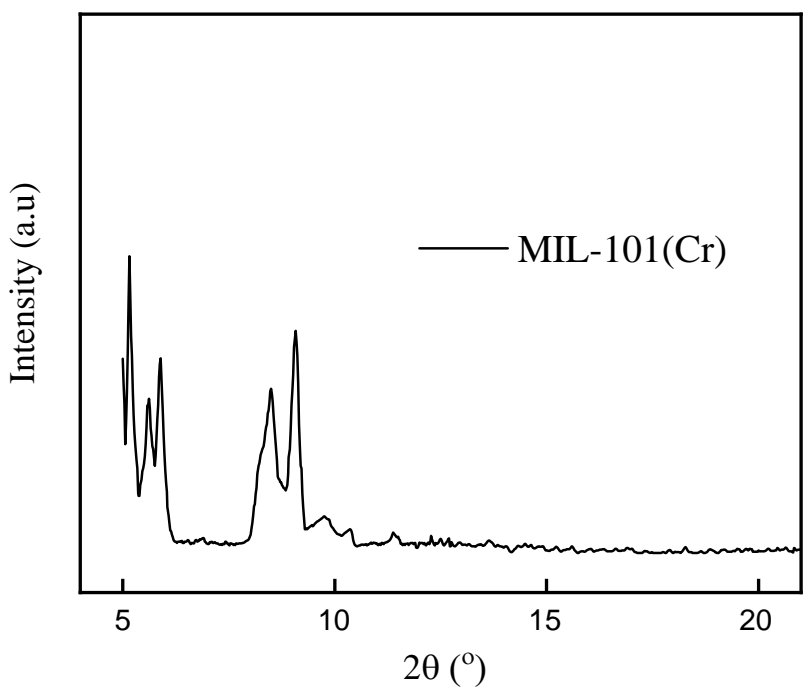

Fig. 2 XRD patterns of the prepared MIL101-Cr sorbent.

The nitrogen adsorption isotherm of the prepared MIL101-Cr sorbent is showed in Fig. 3. The MIL101-Cr sorbent has presented the type-IV adsorption isotherm, according to the IUPAC classification, indicating that the sample has a mesoporous structure which is beneficial to mercury removal ${ }^{37}$. The BET specific surface area and total pore volume of the sample is $2368 \mathrm{~m}^{2} / \mathrm{g}$ and 1.48 $\mathrm{cm}^{3} / \mathrm{g}$, respectively. 


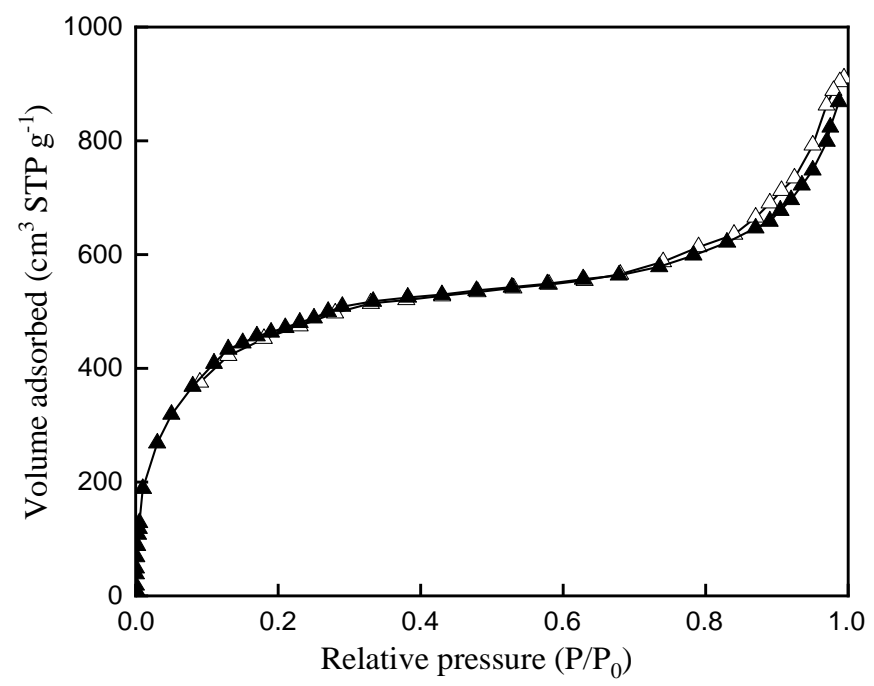

Fig. $3 \mathrm{~N}_{2}$ adsorption-desorption isotherms of MIL101-Cr sorbent.

\subsection{Activity performance}

\subsection{1 $\mathrm{Hg}^{0}$ removal performance}

Fig. 4 shows the $\mathrm{Hg}^{0}$ removal efficiencies of the MIL101-Cr sample within the reaction temperature range of $50-300{ }^{\circ} \mathrm{C}$ under the atmosphere of $\mathrm{N}_{2}+5 \% \mathrm{O}_{2}$. It can be seen that the average $\mathrm{Hg}^{0}$ removal efficiency within $4 \mathrm{~h}$ increased with the reaction temperature, increasing from $50.2 \%$ at $50{ }^{\circ} \mathrm{C}$ to $85.5 \%$ at $200{ }^{\circ} \mathrm{C}$. When the temperature was higher than $200{ }^{\circ} \mathrm{C}$, the mercury removal performance became deteriorated with the reaction temperature: the average $\mathrm{Hg}^{0}$ removal efficiency was $78.5 \%$ at $250{ }^{\circ} \mathrm{C}$ and $70.2 \%$ at $300{ }^{\circ} \mathrm{C}$, respectively. The adsorption of $\mathrm{Hg}^{0}$ on the surface of the MIL101-Cr sorbents is a combination of physisorption and chemisorption. The adsorption of $\mathrm{Hg}^{0}$ through physisorption is favoured at a lower temperature, whereas the chemisorption is related to activation energy and proceeds at a limited rate which increases with the temperature increasing ${ }^{38}$. Hence, a higher reaction temperature is beneficial to the chemisorption. At the temperature of $50{ }^{\circ} \mathrm{C}$, only physisorption could have occurred; however, the total $\mathrm{Hg}^{0}$ removal efficiency was not very low (50.2\%) due to the high 
BET surface area $\left(2368 \mathrm{~m}^{2} / \mathrm{g}\right)$ which can provide more adsorption sites. Since physisorption is easy to reach saturation, the $\mathrm{Hg}^{0}$ adsorption of the $\mathrm{MIL101-Cr}$ sorbent at $50{ }^{\circ} \mathrm{C}$ was quite close to breakthrough after the $4 \mathrm{~h}$ reaction. At higher temperatures, both physisorption and chemisorption contribute to the $\mathrm{Hg}^{0}$ adsorption. However, when the reaction temperature was increased from $200{ }^{\circ} \mathrm{C}$ to $250{ }^{\circ} \mathrm{C}$ and $300{ }^{\circ} \mathrm{C}$, the $\mathrm{Hg}^{0}$ removal ability of the sorbent was seen clearly decreasing with the temperature, which can be attributed to the release of the surface-bound mercury species and the decomposition of mercury oxide ${ }^{39,40}$. From the above results, it can be seen that $200{ }^{\circ} \mathrm{C}$ was the best operating temperature for $\mathrm{Hg}^{0}$ removal over MIL101-Cr, and hence this temperature was selected for the subsequent studies of the $\mathrm{Hg}^{0}$ removal performance.

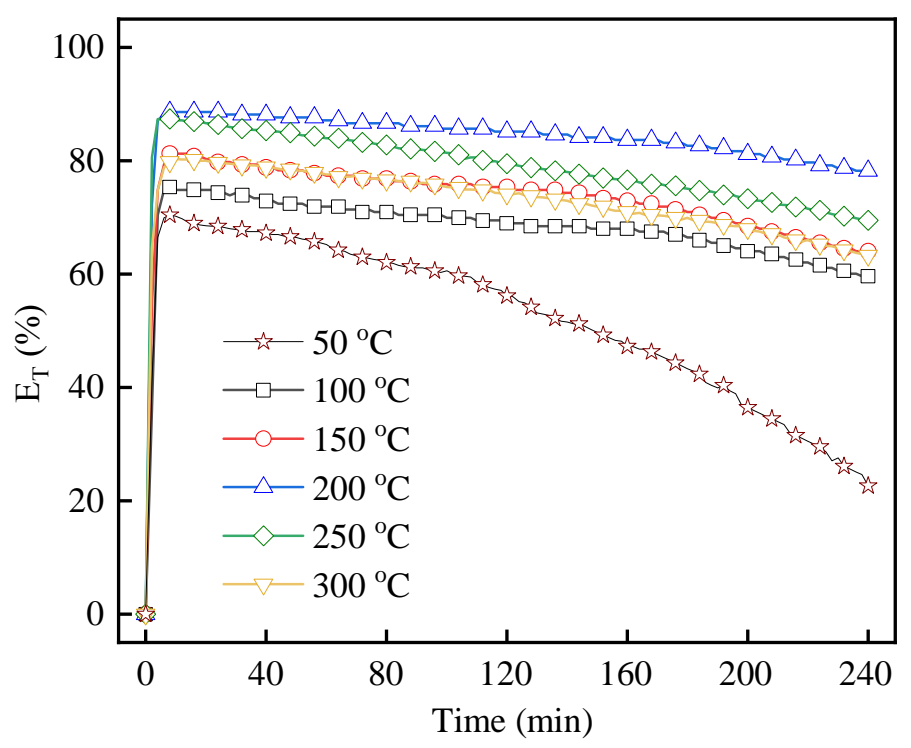

Fig. $4 \mathrm{Hg}^{0}$ removal efficiency over the MIL101-Cr sorbent. (Reaction condition: $\mathrm{N}_{2}+5 \% \mathrm{O}_{2}, 203 \mu \mathrm{g} / \mathrm{m}^{3}, 8 \times 10^{5} \mathrm{~h}^{-1}$ ) 


\subsubsection{Effect of inlet $\mathrm{Hg}^{0}$ concentration and GHSV}

It should be noted that the inlet concentration of $\mathrm{Hg}^{0}$ at $203 \mu \mathrm{g} / \mathrm{m}^{3}$ in the tests of Fig. 4 is far higher than the values in other researchers' investigations ${ }^{4,17}$. Hence, the inlet concentration of $\mathrm{Hg}^{0}$ was reduced to 132 and $74 \mathrm{ug} / \mathrm{m}^{3}$ in order to study its effects on $\mathrm{Hg}^{0}$ removal performance over MIL101Cr. As shown in Fig. 5, higher mercury removal efficiencies (88.8\% and 92.5\%, respectively) were achieved at these lower $\mathrm{Hg}^{0}$ concentrations. Decreasing the inlet $\mathrm{Hg}^{0}$ concentration led to the decrease of the number of mercury molecules through the reactor. Hence, the relative molar ratio of the sorbent to mercury was increased, benefitting the mercury removal ${ }^{41}$. It can be inferred that a very high mercury removal efficiency can be acquired with the MIL101-Cr sorbent in the actual coal-fired flue gas as the mercury concentration in the actual coal-fired flue gases is only ranged from 3 to $30 \mu \mathrm{g} / \mathrm{m}^{3}$, which is much lower than that used in this study.

The GHSV is a crucial parameter for the mercury adsorption performance of sorbents. The effect of GHSV on the $\mathrm{Hg}^{0}$ removal efficiency over the MIL 101-Cr sorbent tested was experimentally investigated and the results are shown in Fig. 5. It can observed that the $\mathrm{Hg}^{0}$ removal efficiency decreased to $65.6 \%$ from $85.5 \%$ when the GHSV increased to $1.6 \times 10^{6} \mathrm{~h}^{-1}$ from $8 \times 10^{5} \mathrm{~h}^{-1}$. An elevated GHSV could led to a shorter residence time of the mercury containing flue gas in the sorbent, resulting in a shorter contact and adsorption time between the mercury and the sorbent. Similar to the results of other studies ${ }^{41,42}$, a better mercury removal performance was acquired when the GHSV was decreased due to a longer residence time between the mercury and the sorbent. The mercury removal efficiency reached to almost $98 \%$ when the GHSV decreased to $2 \times 10^{5} \mathrm{~h}^{-1}$. It is worth noting that the GHSV $\left(8 \times 10^{5} \mathrm{~h}^{-1}\right)$ investigated in this study are much higher compared to other researches ${ }^{41,42}$. 


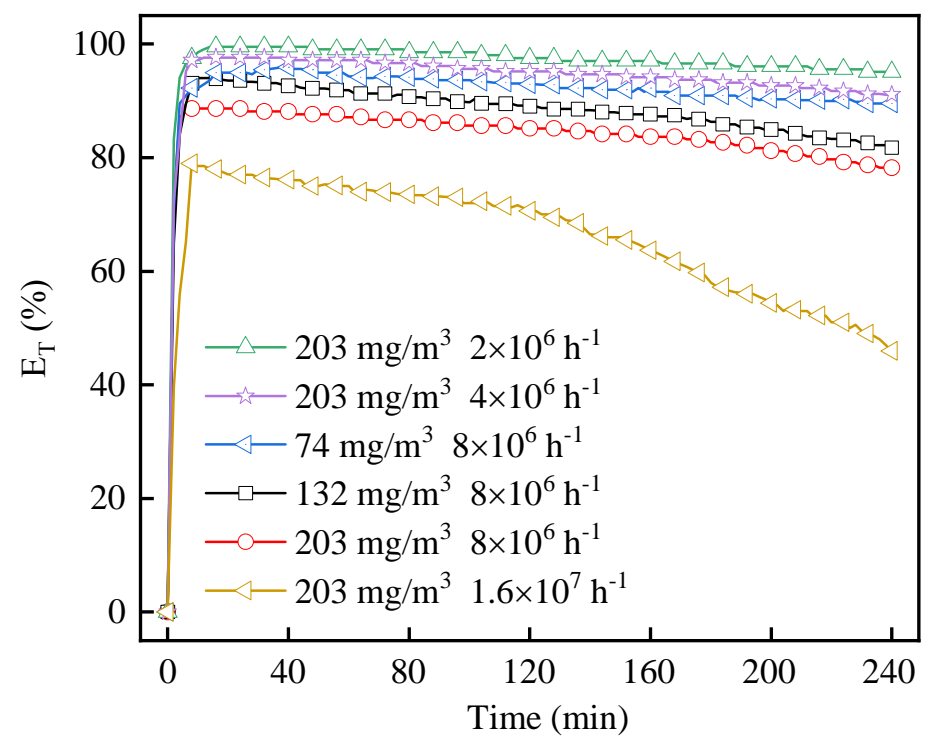

Fig. 5 Effect of inlet $\mathrm{Hg}^{0}$ concentration and GHSV on the $\mathrm{Hg}^{0}$ removal performance. (Reaction condition: $\mathrm{N}_{2}+5 \% \mathrm{O}_{2}, 200{ }^{\circ} \mathrm{C}$ )

\subsubsection{Effect of individual flue gas component}

\subsubsection{Effect of $\mathrm{O}_{2}$}

$\mathrm{O}_{2}$ is an indispensable flue gas component and could play an essential role in $\mathrm{Hg}^{0}$ adsorption reaction. The effect of $\mathrm{O}_{2}$ in the flue gas on the mercury removal performance of the MIL101-Cr sorbent (at $200{ }^{\circ} \mathrm{C}$ ) was experimentally investigated with the flue gases containing different $\mathrm{O}_{2}$ concentrations, and the results are shown in Fig. 6. Fig. 6 clearly shows that the MIL101-Cr sample had a poor performance of $\mathrm{Hg}^{0}$ removal with the flue gas containing no $\mathrm{O}_{2}$, and its $\mathrm{Hg}^{0}$ removal efficiency decreased to lower than $40.0 \%$ after $4 \mathrm{~h}$ adsorption reactions. When the $\mathrm{O}_{2}$ content in the flue gas increased from 0 to $5 \%$ and $10 \%$, the average $\mathrm{Hg}^{0}$ removal efficiency of the MIL101-Cr increased from $60.5 \%$ to $85.5 \%$ and $88.1 \%$, respectively. This indicates that an increase in the $\mathrm{O}_{2}$ concentration could effectively enhance the $\mathrm{Hg}^{0}$ adsorption performance over the MIL101-Cr sorbent. The gas-phase $\mathrm{O}_{2}$ in flue gas could replenish and regenerate the consumed surface oxygen on the adsorbent surface, which serves as the oxidant consumed in the $\mathrm{Hg}^{0}$ oxidation process, thus enhancing 
the $\mathrm{Hg}^{0}$ removal ${ }^{43,44}$. The results in Fig. 6 also show that the $\mathrm{Hg} 0$ removal efficiency at $10 \% \mathrm{O}_{2}$ was only slightly higher $(2.6 \%)$ than that at $5 \% \mathrm{O}_{2}$, implying $5 \% \mathrm{O}_{2}$ in the flue gas was enough for regenerating and replenishing the consumed surface oxygen.

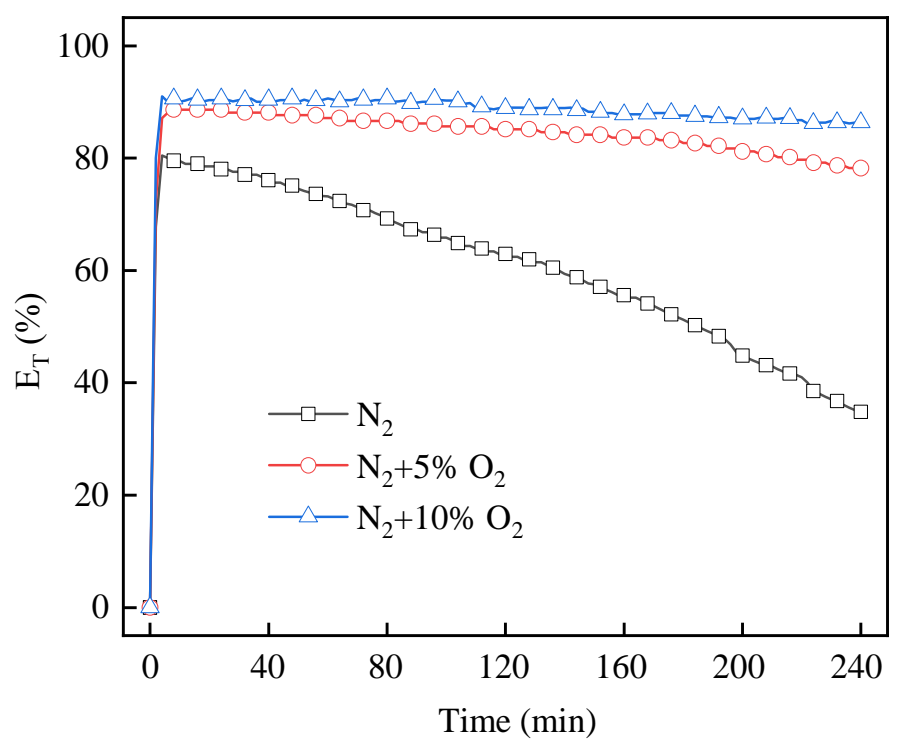

Fig. 6 Effect of $\mathrm{O}_{2}$ concentration on the $\mathrm{Hg}^{0}$ removal performance.

(Reaction condition: $203 \mu \mathrm{g} / \mathrm{m}^{3}, 8 \times 10^{5} \mathrm{~h}^{-1}, 200^{\circ} \mathrm{C}$ )

\subsubsection{Effect of NO}

$\mathrm{NO}$ is one of the main pollutants present in component of coal-fired boiler flue gases. Therefore, $\mathrm{Hg}^{0}$ removal experiments with the MIL101-Cr sorbent were carried out with the flue gases containing different concentrations of NO. The results shown in Fig. 7 indicate that NO in the flue gas facilitated the $\mathrm{Hg}^{0}$ removal both in the absence and presence of $\mathrm{O}_{2}$. Compared with the $\mathrm{Hg}^{0}$ removal performance over the MIL101-Cr sorbent without NO in the pure $\mathrm{N}_{2}$, the addition of $200 \mathrm{ppm}$ NO greatly enhanced the $\mathrm{Hg}^{0}$ removal ability, the average efficiency having increased from $61.5 \%$ to $87.2 \%$. Besides, with the help of $5 \% \mathrm{O}_{2}$, the presence of $200 \mathrm{ppm} \mathrm{NO}$ in the flue gas resulted in the $\mathrm{Hg}^{0}$ removal efficiency to achieve to $93.8 \%$. With further increases of the NO concentration to $600 \mathrm{ppm}$ and $1200 \mathrm{ppm}$, the $\mathrm{Hg}^{0}$ removal efficiency still maintained at about $95.0 \%$. It has been reported that the presence of NO 
could produce the active species such as $\mathrm{NO}_{2}, \mathrm{NO}^{+}$on the surface of the metal based sorbents ${ }^{17,45}$, which can facilitate the oxidation removal of $\mathrm{Hg}^{0}$. From Fig. 7, it can also been seen that the $\mathrm{Hg}^{0}$ removal efficiency of MIL101-Cr with the flue gas containing both $\mathrm{O}_{2}$ and NO was higher than that with the flue gas only having the presence of the NO alone. This can be attributed to the following: in the presence of $\mathrm{O}_{2}$, more adsorbed $\mathrm{NO}$ could be oxidized on the sorbent to form abundant active species like $\mathrm{NO}_{2}$, at the same time, the gas phase $\mathrm{O}_{2}$ could also regenerate the consumed surface oxygen species $^{21}$. The surface chemistry of the used MIL101-Cr sorbent, which had captured the $\mathrm{Hg}^{0}$ included in the atmosphere of $\mathrm{N}_{2}+5 \% \mathrm{O}_{2}+600 \mathrm{ppm} \mathrm{NO}$, was investigated by XPS analysis to identify the nitrogen species on the surface of the sorbent. As shown in Fig. 8, a small peak of the $\mathrm{N} 1 \mathrm{~s}$ spectra appeared at $406.0 \mathrm{eV}$ which can be attributed to $\mathrm{NO}_{2}$ and a big peak appeared at $400.0 \mathrm{eV}$ which can be assigned to $\mathrm{NO}_{3}^{-}$on the surface of the MIL101-Cr sorbent ${ }^{46}$. This confirms that $\mathrm{NO}_{2}$ was produced by the reaction of the NO containing flue gases with the sorbent, and subsequently participated in the $\mathrm{Hg}^{0}$ oxidation process to form $\mathrm{Hg}\left(\mathrm{NO}_{3}\right)_{2}$. The reactions involved in these processes can be described as follows (5-11).

$$
\begin{gathered}
\mathrm{NO}(\mathrm{g})+\text { adsorbent surface } \rightarrow \mathrm{NO}(\text { ads }) \\
\mathrm{NO}(\text { ads })+\mathrm{O}(\text { surface }) \rightarrow \mathrm{NO}_{2}(\text { ads }) \\
\mathrm{O}_{2}(\mathrm{~g}) \rightarrow \mathrm{O}_{2} \text { (ads) } \\
\left.\left.\mathrm{NO}(\text { ads })+\mathrm{O}_{2} \text { (ads }\right) \rightarrow \mathrm{NO}_{2} \text { (ads }\right)+\mathrm{O} \\
\mathrm{Hg}^{0}(\mathrm{~g}) \rightarrow \mathrm{Hg}^{0}(\text { ads }) \\
\left.\mathrm{Hg}^{0}(\text { ads })+\mathrm{NO}_{2} \text { (ads }\right) \rightarrow \mathrm{HgO}(\text { ads })+\mathrm{NO}(\text { ads }) \\
\left.\left.\left.\mathrm{Hg}^{0} \text { (ads }\right)+\mathrm{NO}_{2} \text { (ads }\right)+\mathrm{O}_{2}(\mathrm{~g}) \rightarrow \mathrm{Hg}\left(\mathrm{NO}_{3}\right)_{2} \text { (ads }\right)
\end{gathered}
$$




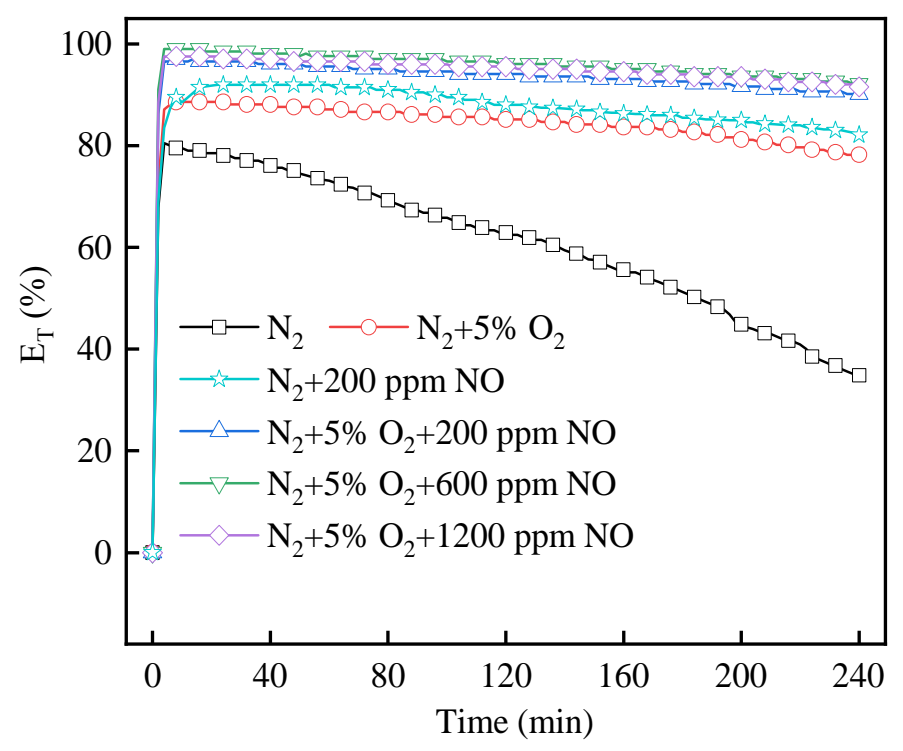

Fig. 7 Effect of $\mathrm{NO}$ concentration on the $\mathrm{Hg}^{0}$ removal performance.

(Reaction condition: $203 \mu \mathrm{g} / \mathrm{m}^{3}, 8 \times 10^{5} \mathrm{~h}^{-1}, 200{ }^{\circ} \mathrm{C}$ )

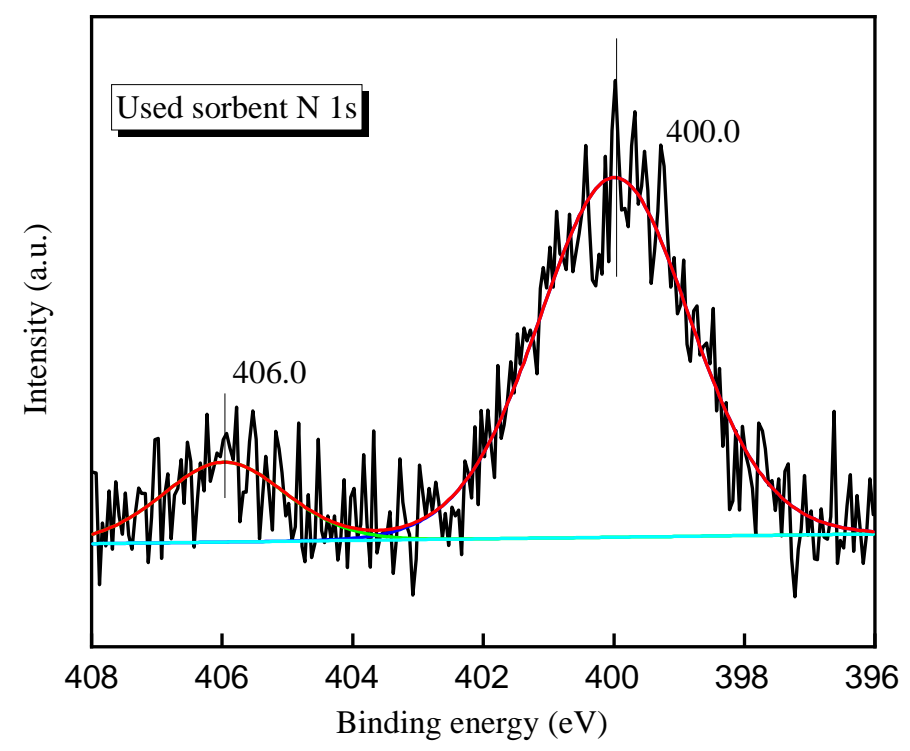

Fig. 8 XPS spectra of the used MIL101-Cr sorbent over the N 1s spectral.

(Reaction condition: $\mathrm{N}_{2}+5 \% \mathrm{O}_{2}+600 \mathrm{ppm} \mathrm{NO}, 203 \mu \mathrm{g} / \mathrm{m}^{3}, 8 \times 10^{5} \mathrm{~h}^{-1}, 200{ }^{\circ} \mathrm{C}, 2 \mathrm{~h}$ )

\subsubsection{Effect of $\mathrm{SO}_{2}$}

As another main pollutant present in coal-fired boiler flue gases, $\mathrm{SO}_{2}$ has been proved to play an crucial role in $\mathrm{Hg}^{0}$ removal process over many sorbents ${ }^{32,39,40}$. The effect of the $\mathrm{SO}_{2}$ in the flue gas on the performance of $\mathrm{Hg}^{0}$ removal over the MIL101-Cr sorbent used in this study is shown in Fig. 9. 
The presence of $\mathrm{SO}_{2}$ in the flue gas had an obvious inhibiting effect on the $\mathrm{Hg}^{0}$ removal. When 200 ppm $\mathrm{SO}_{2}$ was introduced to the pure $\mathrm{N}_{2}$ gas stream, the average $\mathrm{Hg}^{0}$ removal efficiency within $4 \mathrm{~h}$ decreased from $61.5 \%$ to $39.8 \%$, which could be ascribed to the consumption of the surface active oxygen species by the reaction of $\mathrm{SO}_{2}$ (Eq. 12) and the competitive adsorptions between $\mathrm{SO}_{2}$ and $\mathrm{Hg}^{0}$ for the surface active sites ${ }^{47}$. In order to further prove the competitive adsorptions between $\mathrm{SO}_{2}$ and $\mathrm{Hg}^{0}$, the desorption experiment was carried out following the procedure shown in Fig. 10. The MIL101-Cr sample was first pretreated under the condition of $\mathrm{Hg}^{0}+\mathrm{N}_{2}$ at $200{ }^{\circ} \mathrm{C}$ for 60 min, then the feeding of $\mathrm{Hg}^{0}$ was cut off and the mercury-loaded sample was purged in $\mathrm{N}_{2}$ for 30 min to remove the surface weakly adsorbed mercury. After the $\mathrm{N}_{2}$ purging, $1200 \mathrm{ppm} \mathrm{SO}_{2}$ was added to the simulated flue gas (pure $\mathrm{N}_{2}$ in this case). The results in Fig. 10 clearly show that the $\mathrm{Hg}^{0}$ concentration at the exit of the reactor increased immediately when $\mathrm{SO}_{2}$ was introduced to the flue gas, increasing from about 0 to $54.2 \mu \mathrm{g} / \mathrm{m}^{3}$. This suggests that the introduced $\mathrm{SO}_{2}$ had replaced the surface bond mercury, i.e. made part of the surface mercury desorb at $200{ }^{\circ} \mathrm{C}$, indicating the competitive adsorptions of $\mathrm{SO}_{2}$ and $\mathrm{Hg}^{0}$ would occur over the MIL101-Cr sorbent. The results in Fig. 9 show that the presence of 5\% $\mathrm{O}_{2}$ in the flue gas had significantly weaken the inhibiting effect of $\mathrm{SO}_{2}$ on the $\mathrm{Hg}^{0}$ removal efficiency which was still higher than $71.0 \%$ after $4 \mathrm{~h}$ adsorption under the conditions of $5 \% \mathrm{O}_{2}$ plus $200 \mathrm{ppm}$ $\mathrm{SO}_{2}$. This can be attributed to the beneficial effect of $\mathrm{O}_{2}$ on the oxidation of $\mathrm{Hg}^{0}$, and the replenishment and regeneration of the consumed surface oxygen by the gaseous $\mathrm{O}_{2}$. Besides, $\mathrm{SO}_{2}$ can react with $\mathrm{O}_{2}$ to produce $\mathrm{SO}_{3}{ }^{40}$, which is favourable to the chemisorption of $\mathrm{Hg}^{0}$ (Eqs. 13-14). Therefore, a low concentration of $\mathrm{SO}_{2}(200 \mathrm{ppm})$ with the presence of $5 \% \mathrm{O}_{2}$ slightly impeded the $\mathrm{Hg}^{0}$ removal by the MIL101-Cr sorbent. However, further increasing the $\mathrm{SO}_{2}$ concentration in the flue gas to $600 \mathrm{ppm}$ and 
$1200 \mathrm{ppm}$ resulted in much lower $\mathrm{Hg}^{0}$ average removal efficiency within $4 \mathrm{~h}$, to $53.5 \%$ and $45.1 \%$ (Fig.8), respectively. The reduction of $\mathrm{Hg}^{0}$ removal performance could be explained by the inhibition effects of competitive adsorption between $\mathrm{SO}_{2}$ and $\mathrm{Hg}^{0}$ and the surface sulfation of MIL101-Cr, which could counteract the promotion of $\mathrm{SO}_{3}$ for the oxidization of $\mathrm{Hg}^{0}{ }^{17}$. In order to verify if $\mathrm{SO}_{2}$ had reacted with the MIL101-Cr leading to the reduction of its $\mathrm{Hg}^{0}$ removal ability, the $\mathrm{Hg}^{0}$ removal experiment over the $\mathrm{SO}_{2}$ pretreated sorbent was performed and the results are shown in Fig. 11. The MIL101-Cr sorbent was first pretreated with 1200 ppm SO 2 under the $\mathrm{N}_{2}+5 \% \mathrm{O}_{2}$ atmosphere at 200 ${ }^{\circ} \mathrm{C}$ for $60 \mathrm{~min}$ before the $\mathrm{Hg}^{0}$ adsorption test in order to eliminate the effect of competitive adsorptions between $\mathrm{SO}_{2}$ and $\mathrm{Hg}^{0}$. It can be observed from Fig. 11, that the $\mathrm{Hg}^{0}$ removal efficiency over the $\mathrm{SO}_{2}$ pretreated MIL101-Cr sorbent was much lower than that of the fresh MIL101-Cr sorbent. This confirms the assumption that $\mathrm{SO}_{2}$ could react with the MIL101-Cr resulting in the formation of inativative species such as sulfate species which would impair the $\mathrm{Hg}^{0}$ removal ability. The surface chemistry of the used MIL101-Cr sorbent, which was pretreated with $\mathrm{N}_{2}+5 \% \mathrm{O}_{2}+1200$ ppm $\mathrm{SO}_{2}$, was identified by XPS to ascertain this inference. As shown in Fig. 12, the $\mathrm{S} 2 \mathrm{p}$ peaks mainly centered at $168.9 \mathrm{eV}$, which is attributed to $\mathrm{SO}_{4}^{2-}$. This further indicates that $\mathrm{SO}_{2}$ can react with the MIL101-Cr sorbent to form sulfate, which is detrimental to $\mathrm{Hg}^{0}$ removal.

$$
\begin{gathered}
\mathrm{SO}_{2}(\text { ads })+\mathrm{O}(\text { surface }) \rightarrow \mathrm{SO}_{3}(\text { ads }) \\
2 \mathrm{SO}_{2} \text { (ads) }+\mathrm{O}_{2} \rightarrow 2 \mathrm{SO}_{3}(\text { ads }) \\
\mathrm{Hg}^{0}(\text { ads })+\mathrm{O}_{2}+\mathrm{SO}_{3}(\text { ads }) \rightarrow 2 \mathrm{HgSO}_{4}(\text { ads })
\end{gathered}
$$




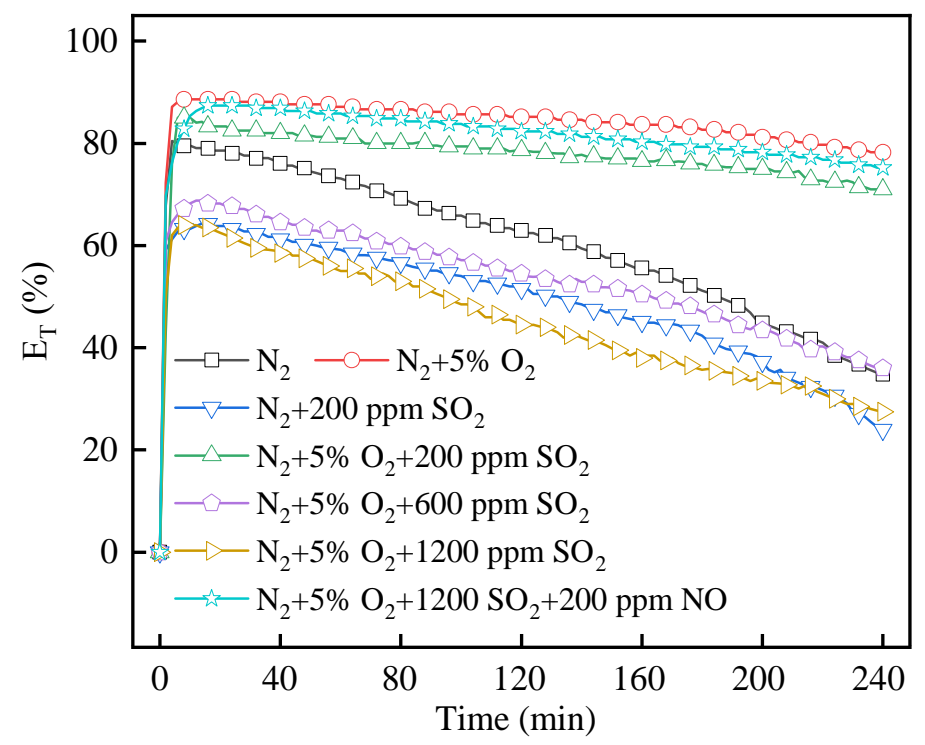

Fig. 9 Effect of $\mathrm{SO}_{2}$ concentration on the $\mathrm{Hg}^{0}$ removal performance.

(Reaction condition: $203 \mu \mathrm{g} / \mathrm{m}^{3}, 8 \times 10^{5} \mathrm{~h}^{-1}, 200{ }^{\circ} \mathrm{C}$ )

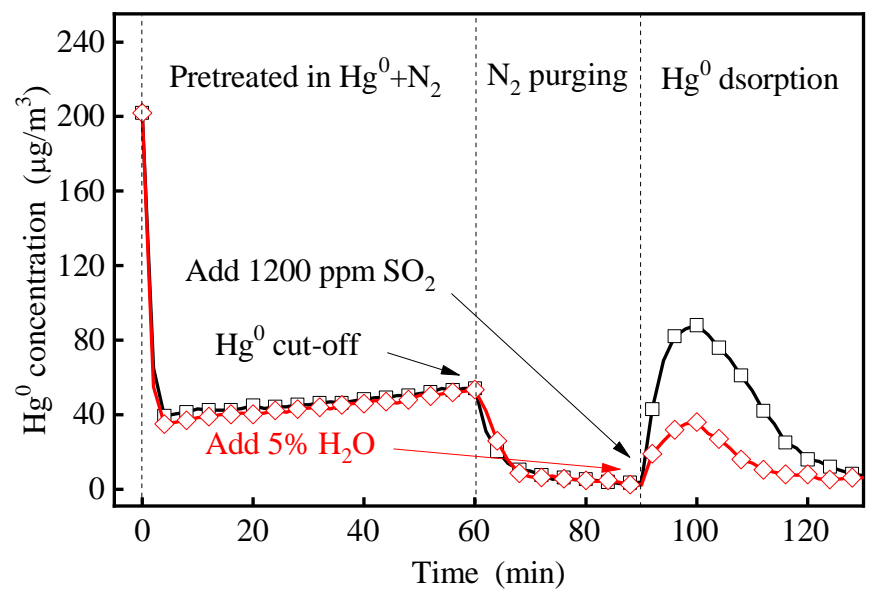

Fig. $10 \mathrm{Hg}^{0}$ desorption by $\mathrm{SO}_{2}$ or $\mathrm{H}_{2} \mathrm{O}$ over MIL101-Cr at $200{ }^{\circ} \mathrm{C}$.

(Reaction condition: $8 \times 10^{5} \mathrm{~h}^{-1}, 200{ }^{\circ} \mathrm{C}$ ) 


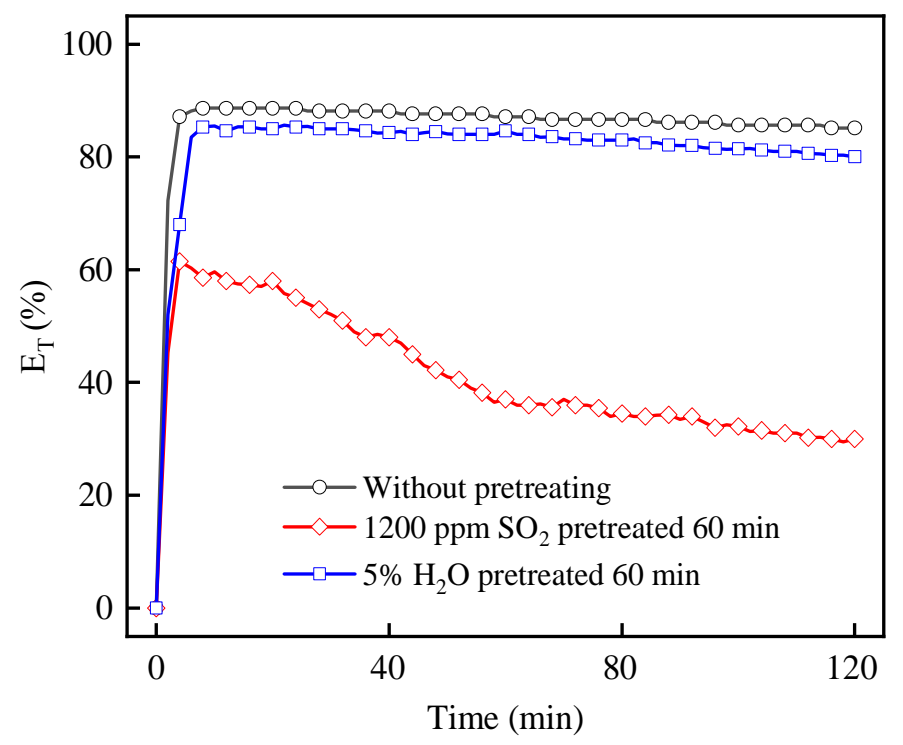

Fig. $11 \mathrm{Hg}^{0}$ removal performance over the $\mathrm{SO}_{2}$ or $\mathrm{H}_{2} \mathrm{O}$ pretreated MIL101-Cr.

(Reaction condition: $\mathrm{N}_{2}+5 \% \mathrm{O}_{2}, 203 \mu \mathrm{g} / \mathrm{m}^{3}, 8 \times 10^{5} \mathrm{~h}^{-1}, 200{ }^{\circ} \mathrm{C}$ )

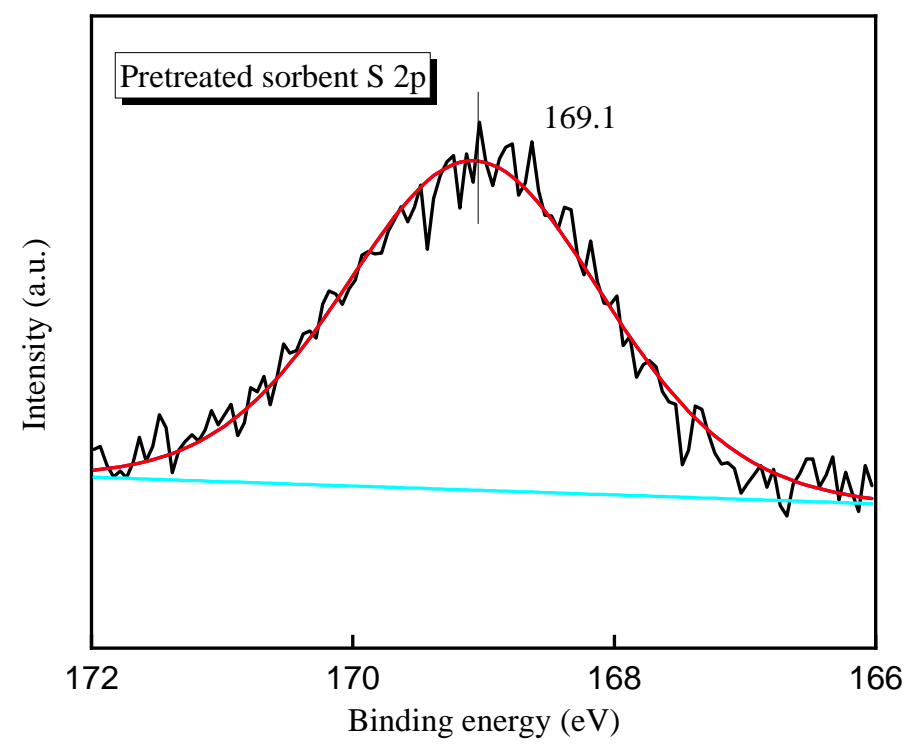

Fig. 12 XPS spectra of the pretreated MIL101-Cr sorbent over the S 2p spectral.

(Reaction condition: $\mathrm{N}_{2}+5 \% \mathrm{O}_{2}+1200 \mathrm{ppm} \mathrm{SO}_{2}, 8 \times 10^{5} \mathrm{~h}^{-1}, 200{ }^{\circ} \mathrm{C}, 2 \mathrm{~h}$ )

As depicted in section 3.2.3.2, the presence of NO could enhance the $\mathrm{Hg}^{0}$ removal over the MIL101-

$\mathrm{Cr}$ sorbent. Therefore, the effects of the simulataneous presence of $200 \mathrm{ppm} \mathrm{NO}$ and $1200 \mathrm{ppm} \mathrm{SO}_{2}$ 
on the $\mathrm{Hg}^{0}$ adsorption wereas also investigated in this study and the results, also shown in Fig. 9, clearly indicate that the inhibition effect of $\mathrm{SO}_{2}$ on the $\mathrm{Hg}^{0}$ removal activity was greatly alleviated by the introduction of NO. The $\mathrm{Hg}^{0}$ removal efficiency reached $81.3 \%$ when 200 ppm NO and 1200 ppm $\mathrm{SO}_{2}$ were introduced to $\mathrm{N}_{2}+5 \% \mathrm{O}_{2}$, which was much higher than that was achieved with the flue gas of $\mathrm{N}_{2}+5 \% \mathrm{O}_{2}+1200 \mathrm{ppm} \mathrm{SO}_{2}$. This can be partly ascribed to the formation of $\mathrm{NO}^{+}$and $\mathrm{NO}_{2}$ as a result of the introduction of $\mathrm{NO}$, and partly due to the oxidization of $\mathrm{SO}_{2}$ to $\mathrm{SO}_{3}$ by $\mathrm{NO}_{2}$ and $\mathrm{O}_{2}$. As $\mathrm{NO}$ always exists in the actual coal-fired flue gas, $\mathrm{NO}$ can partly offset the inhibitory effect of $\mathrm{SO}_{2}$ on the $\mathrm{Hg}^{0}$ removal by the sorbent.

\subsubsection{Effect of $\mathrm{H}_{2} \mathrm{O}$}

$\mathrm{H}_{2} \mathrm{O}$ always exists in real flue gases. Thus, the effect of $\mathrm{H}_{2} \mathrm{O}$ in the flue gas on $\mathrm{Hg}^{0}$ removal was investigated in this study. From Fig. 13, it can be seen that the $\mathrm{Hg}^{0}$ removal efficiency decreased from $87.1 \%$ to $81.4 \%$ when $5 \%$ of $\mathrm{H}_{2} \mathrm{O}$ was added. After 60 min reaction, the $\mathrm{Hg}^{0}$ removal efficiency was slightly reduced to $78.4 \%$, whereas the efficiency increased to $83.6 \%$ when the water vapour was cut off. The results indicate that the presence of $\mathrm{H}_{2} \mathrm{O}$ in the flue gas negatively affected the mercury removal performance over the MIL101-Cr. This is largely due to the competitive adsorptions between $\mathrm{H}_{2} \mathrm{O}$ and $\mathrm{Hg}^{0}$ and/or the $\mathrm{H}_{2} \mathrm{O}$ vapour covering the active adsorption sites for $\mathrm{Hg}^{0}{ }^{48}$, ${ }^{49} \cdot \mathrm{The}^{\mathrm{Hg}} \mathrm{Hg}^{0}$ desorption experiment and the $\mathrm{Hg}^{0}$ adsorption experiment with the $5 \% \mathrm{H}_{2} \mathrm{O}$ pretreated sorbent similar to those described in section 3.2.3.3 were performed to ascertain these two effects as shown in Figs. 10 and 11 . It can be seen from Fig. 10 that a spike of $\mathrm{Hg}^{0}$ was appeared after adding $5 \% \mathrm{H}_{2} \mathrm{O}$ due to the desorption of the surface adsorbed mercury. However, as shown in Fig. 111, the $\mathrm{Hg}^{0}$ removal efficiency with the $5 \% \mathrm{H}_{2} \mathrm{O}$ pretreated sorbent was almost as high as that of the fresh sorbent, 
indicating the MIL101-Cr sorbent pretreated with $5 \% \mathrm{H}_{2} \mathrm{O}$ has insignificant impact on the $\mathrm{Hg}^{0}$ removal ability. Therefore, it can be concluded that the competitive adsorption instead of the surface site deactivation was responsible for the reduced adsorption ability when $\mathrm{H}_{2} \mathrm{O}$ was present in the flue gas.

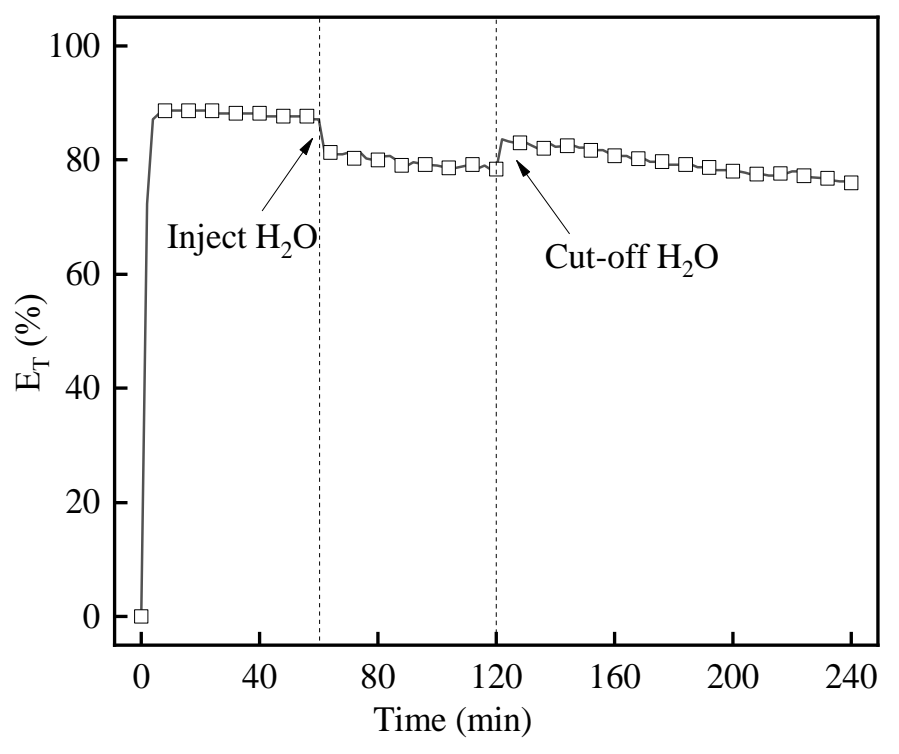

Fig. 13 Effect of $\mathrm{H}_{2} \mathrm{O}$ concentration on the $\mathrm{Hg}^{0}$ removal performance. (Reaction condition: $\mathrm{N}_{2}+5 \% \mathrm{O}_{2}, 203 \mu \mathrm{g} / \mathrm{m}^{3}, 8 \times 10^{5} \mathrm{~h}^{-1}, 200{ }^{\circ} \mathrm{C}$ )

\subsubsection{Comparison of the $\mathrm{Hg}^{0}$ adsorption capacity between MIL101-Cr and commercial AC}

In order to compare the $\mathrm{Hg}^{0}$ removal performance of the MIL101-Cr sorbent with that of a standard $\mathrm{Hg}^{0}$ adsorbent, the commercial $\mathrm{Br}-\mathrm{AC}$ was selected and used to remove $\mathrm{Hg}^{0}$ under the same reaction conditions. As shown above, $\mathrm{O}_{2}, \mathrm{SO}_{2}, \mathrm{NO}$ and $\mathrm{H}_{2} \mathrm{O}$ in the coal-fired flue gas have various effects on the $\mathrm{Hg}^{0}$ removal performance of the MIL101-Cr sorbent. Hence, the simulated flue gas (SFG) containing 5\% $\mathrm{O}_{2}, 200$ ppm NO, $1200 \mathrm{ppm} \mathrm{SO}_{2}$ and $5 \% \mathrm{H}_{2} \mathrm{O}$, balanced with $\mathrm{N}_{2}$, was used for the $\mathrm{Hg}^{0}$ removal performance with the MIL101-Cr sorbent and commercial $\mathrm{Br}-\mathrm{AC}$ at the optimal reaction temperature of $200{ }^{\circ} \mathrm{C}$. As shown in Fig. 14 (a) for the MIL101-Cr sorbent, the $\mathrm{Hg}^{0}$ removal performance under the SFG atmosphere was only slightly worse than that under the atmosphere of 
$\mathrm{N}_{2}+5 \% \mathrm{O}_{2}$. The results shown above that already confirmed both $\mathrm{SO}_{2}$ and $\mathrm{H}_{2} \mathrm{O}$ had inhibiting effects on the mercury removal performance, while NO could enhance the $\mathrm{Hg}^{0}$ removal ability. Hence, the presence of $\mathrm{NO}$ in the flue gas can counteract the adverse effects of $\mathrm{SO}_{2}$ and $\mathrm{H}_{2} \mathrm{O}$. Under the same SFG atmosphere the commercial $\mathrm{Br}-\mathrm{AC}$ had a much worse $\mathrm{Hg}^{0}$ removal performance in comparison with the MIL101-Cr sorbent (Fig. 14 (a)). After 240 min reactions, the mercury removal efficiency of the commercial Br-AC decreased to $28.4 \%$, while the $\mathrm{Hg}^{0}$ removal efficiency of the MIL101-Cr sorbent maintained above $70 \%$. This means that the commercial $\mathrm{Br}-\mathrm{AC}$ almost reached the mercury adsorption saturation after 240 min, whereas the MIL101-Cr sorbent still had the good ability to further adsorb mercury. The accumulated mercury adsorption capacities $\left(\mathrm{q}_{\mathrm{t}}\right)$ at 240 min were calculated according to Eq. 4 and are shown in Fig. 14 (b). It can be seen that the q value of the commercial BrAC under the SFG condition was only $472.2 \mu \mathrm{g} / \mathrm{g}$, while for the MIL101-Cr sorbent, the $\mathrm{q}_{\mathrm{t}}$ value reached $770.2 \mu \mathrm{g} / \mathrm{g}$, which was over $60 \%$ higher than that of the commercial Br-AC. As will be shown in Section 3.3.3, the equilibrium mercury adsorption capacity of the MIL101-Cr sorbent can be calculated to be as high as $25656 \mu \mathrm{g} / \mathrm{g}$. The comparison of the mercury adsorption capacity between the MIL101-Cr sorbent and other sorbents evaluated by other researchers is presented in Table 1. Clearly, the MIL101-Cr sorbent evaluated in this study can be considered as an outstanding mercury sorbent due to its largest specific surface area, excellent mercury removal efficiency and high mercury adsorption capacity.

Although it is true that the synthetic cost of the MIL101-Cr sorbent is higher than that of the commercial $\mathrm{Br}-\mathrm{AC}$, it should be noted that introducing a magnetic medium (such as $\mathrm{Fe}_{3} \mathrm{O}_{4}$ or $\gamma-\mathrm{Fe}_{2} \mathrm{O}_{3}$ ) into this MOF material can make this sorbent magnetic and hence become reuseable and recyclable. 
These kinds of magnetic MOF materials have been applied into the fields of organophosphate esters sorption ${ }^{50}$ and luminol chemiluminescence catalysis ${ }^{51}$, and can also be applied as efficient and economic magnetic mercury sorbents for $\mathrm{Hg}^{0}$ removal from coal-fired boiler flue gases.
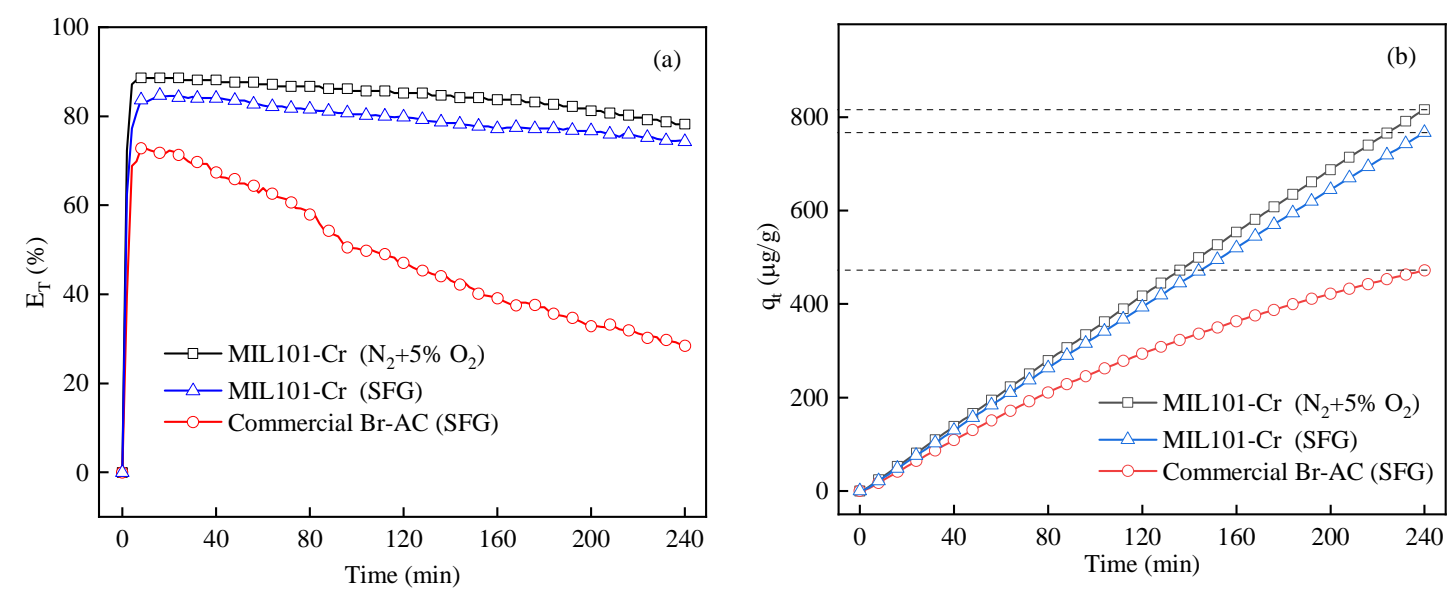

Fig. $14 \mathrm{Hg}^{0}$ removal efficiencies (a) and adsorption capacities (b) of MIL101-Cr and commercial $\mathrm{Br}$ AC. (Reaction condition: $203 \mu \mathrm{g} / \mathrm{m}^{3}, 8 \times 10^{5} \mathrm{~h}^{-1}, 200{ }^{\circ} \mathrm{C}$ )

Table 1 Comparison of $\mathrm{Hg}^{0}$ adsorption capacity of the MIL101-Cr with other sorbents.

\begin{tabular}{|c|c|c|c|c|}
\hline Sorbents & $\begin{array}{l}\text { Adsorption } \\
\text { temperature }\left({ }^{\circ} \mathrm{C}\right)\end{array}$ & $\begin{array}{l}\text { BET surface area } \\
\left(\mathrm{m}^{2} / \mathrm{g}\right)\end{array}$ & $\mathrm{q}_{\mathrm{e}}(\mu \mathrm{g} / \mathrm{g})$ & References \\
\hline $\mathrm{Fe}_{1.5} \mathrm{MBC}_{600}$ & 150 & 657.24 & 1279.6 & 52 \\
\hline S8Br5 & 160 & 19.66 & 952.4 & 10 \\
\hline Br-CAC & 145 & 438 & 585.0 & 38 \\
\hline FC-20 & 150 & 42.43 & 473.93 & 53 \\
\hline T6W1P1 & 140 & 17.5 & 353.36 & 5 \\
\hline MIL101-Cr & 200 & 2368 & 25656 & This work \\
\hline
\end{tabular}

\subsection{Discussion on the mechanism of $\mathbf{H g}^{0}$ removal}

\subsubsection{Identification of the $\mathrm{Hg}^{\mathbf{0}}$ adsorption and oxidation behaviors over MIL101-Cr}

The $\mathrm{Hg}^{0}$ adsorption and oxidation behaviors over the MIL101-Cr sorbent were studied by using the mercury speciation conversion system. As it can be seen from Fig. 15 (a), when $\mathrm{Hg}^{0}$ was passing through the MIL101-Cr sorbent, the outlet $\mathrm{Hg}^{0}$ and $\mathrm{Hg}^{\mathrm{T}}$ concentrations decreased from $203 \mathrm{ug} / \mathrm{m}^{3}$ to $44.2 \mu \mathrm{g} / \mathrm{m}^{3}$ and $59.5 \mu \mathrm{g} / \mathrm{m}^{3}$ after $240 \mathrm{~min}$ reaction at $200{ }^{\circ} \mathrm{C}$, respectively. The difference between the $\mathrm{Hg}^{\mathrm{T}}$ and $\mathrm{Hg}^{0}$ concentrations, which can be defined as the concentration of $\mathrm{Hg}^{2+}$, increased gradually 
with the reaction time, reaching to $13.3 \mu \mathrm{g} / \mathrm{m}^{3}$ after $4 \mathrm{~h}$ of reaction. This indicates that the most mercury species, included $\mathrm{Hg}^{0}$ and/or $\mathrm{Hg}^{2+}$, were retained on the surface of the MIL101-Cr sorbent. Fig. 15 (b) shows the $\mathrm{Hg}^{0}$ adsorption and oxidation efficiencies over the MIL101-Cr sorbent at various reaction temperatures $\left(50-300{ }^{\circ} \mathrm{C}\right.$ ). At $50{ }^{\circ} \mathrm{C}$, almost no $\mathrm{Hg}^{2+}$ was observed at the outlet of the flue gas as the low temperature inhibited the oxidation of $\mathrm{Hg}^{0}$. It can be observed from Fig. 15 (b) that the variation trend of the $\mathrm{Hg}^{0}$ adsorption efficiency ( $\mathrm{E}_{\mathrm{ads}}$ ) is the same as the $\mathrm{Hg}^{0}$ removal efficiency $\left(\mathrm{E}_{\mathrm{T}}\right)$. As the reaction temperature was increased from $100{ }^{\circ} \mathrm{C}$ to $300{ }^{\circ} \mathrm{C}$, the $\mathrm{Hg}^{0}$ oxidation efficiency $\left(\mathrm{E}_{\text {oxi }}\right)$ increased from $1.9 \%$ to $13.5 \%$, indicating more $\mathrm{Hg}^{0}$ being oxidized at the elevated reaction temperature. However, the $\mathrm{Hg}^{0}$ oxidation efficiency was still very low in comparison to the $\mathrm{E}_{\mathrm{ads}}$ at various reaction temperatures. At the temperature of $200{ }^{\circ} \mathrm{C}$ in this study, the $\mathrm{E}_{\mathrm{ads}}$ and the $\mathrm{E}_{\text {oxi }}$ were $81.6 \%$ and $3.9 \%$, respectively. Hence, it can be concluded that the chemical adsorption of $\mathrm{Hg}^{0}$ was the dominant mechanism in the $\mathrm{Hg}^{0}$ removal process. The $\mathrm{Hg}^{0}$ removal process over the MIL101-Cr sorbent belongs to the chemisorption reaction rather than to the heterogeneous catalysis.
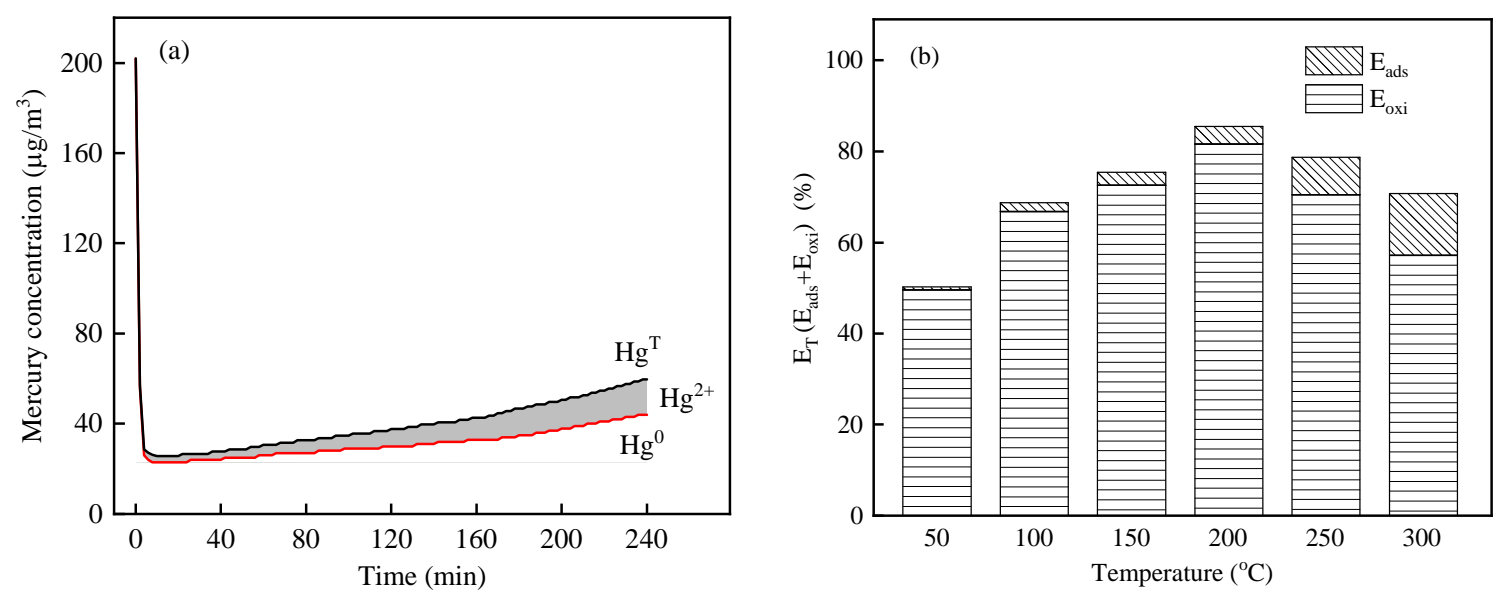

Fig. 15 (a) The outlet $\mathrm{Hg}^{0}, \mathrm{Hg}^{2+}$, and $\mathrm{Hg}^{\mathrm{T}}$ concentrations under the reaction temperature of $200{ }^{\circ} \mathrm{C}$; (b) $\mathrm{Hg}^{0}$ adsorption and oxidation efficiency at various reaction temperatures. 


$$
\text { (Reaction condition: } 203 \mu \mathrm{g} / \mathrm{m}^{3}, 8 \times 10^{5} \mathrm{~h}^{-1} \text { ) }
$$

\subsubsection{XPS analysis}

To further understand the mechanism of $\mathrm{Hg}^{0}$ removal by the MIL 101-Cr sample, the chemistry valence of the elements on the surface of the MIL 101-Cr sample was determined by the XPS technique. The XPS spectra of $\mathrm{Cr} 2 \mathrm{p}, \mathrm{C}$ 1s, O 1s and $\mathrm{Hg}$ 4f for the fresh and used MIL101-Cr samples are shown in Fig. 16. The surface atomic concentrations and surface atomic ratios based on the XPS results are summarized in Table 2.

The XPS spectra of O 1s for the fresh and used samples are shown in Fig. 16 (a). It can be seen that three different oxygen peaks were observed on both samples. The peak at about $530.2 \mathrm{eV}$ was attributed to lattice oxygen $\left(\mathrm{O}^{2-}\right)^{4}$, and the peak at about $531.5 \mathrm{eV}$ was assigned to the chemisorbed oxygen and/or weakly bonded oxygen species $\left(\mathrm{O}^{*}\right)^{54}$. The third peak at around $533.0 \mathrm{eV}$ was related to the generation of $\mathrm{C}-\mathrm{O}{ }^{52,55}$. After $\mathrm{Hg}^{0}$ adsorption tests, the content of $\mathrm{O}^{2-}$ increased from $70.2 \%$ to $77.5 \%$, while the content of $\mathrm{O}^{*}$ decreased from $23.4 \%$ to $10.3 \%$ (Table 2 ). The decreasing of $\mathrm{O}^{*}$ in the used MIL101-Cr indicated that $\mathrm{O}^{*}$ participated in the $\mathrm{Hg}^{0}$ removal reaction. The increasing of $\mathrm{O}^{2-}$ in the used MIL101-Cr sample could be due to the appearance of $\mathrm{O}^{2-}$ in $\mathrm{HgO}$ (Eqs. 15-16) ${ }^{52}$. Furthermore, the increase of $\mathrm{C}-\mathrm{O}$ might be due to some active $\mathrm{O}^{*}$ species being transformed into C-O groups during the process of $\mathrm{Hg}^{0}$ removal ${ }^{10}$.

$$
\begin{gathered}
\mathrm{Hg}^{0}(\mathrm{~g}) \rightarrow \mathrm{Hg}^{0} \text { (ads) } \\
\text { Sorbent-O* }+\mathrm{Hg}^{0} \text { (ads) } \rightarrow \text { Sorbent-HgO(ads) }
\end{gathered}
$$

From the XPS spectra of Cr 2p shown in Fig. 16 (b), it can be seen that two peaks centered at about $577.1 \mathrm{eV}$ and $586.7 \mathrm{eV}$ ascribed to $\mathrm{Cr}^{3+56}$. A weak peak belonging to $\mathrm{Cr}^{2+}$ could be observed for the used MIL101-Cr sorbent at the binding energy of $576.3 \mathrm{eV}^{4}$. According to previous research, the $\mathrm{Cr}^{3+}$ 
on the surface could reduce to $\mathrm{Cr}^{2+}$ during the process of $\mathrm{Hg}^{0}$ oxidization. But in the presence of $\mathrm{O}_{2}$, $\mathrm{Cr}^{2+}$ could be oxidized to $\mathrm{Cr}^{3+}$ again by the surface chemisorbed oxygen. The intensity for $\mathrm{Cr} 2 \mathrm{p}$ peaks became weaker after the reaction, indicating the combination of $\mathrm{Cr}$ sites and mercury species occurred during the $\mathrm{Hg}^{0}$ removal process. The involving pathways of the $\mathrm{Hg}^{0}$ oxidization in relate to $\mathrm{Cr}^{3+} / \mathrm{Cr}^{2+}$ and oxygen species could be described as follows (Eqs. 17-18).

$$
\begin{gathered}
2 \mathrm{Cr}^{3+}+\mathrm{Hg}^{0} \text { (ads) } \rightarrow 2 \mathrm{Cr}^{2+}+\mathrm{Hg}^{2+}(\text { ads }) \\
2 \mathrm{Cr}^{2+}+\mathrm{O}(\text { surface }) \rightarrow 2 \mathrm{Cr}^{3+}+\mathrm{O}^{2-}(\text { surface })
\end{gathered}
$$

The XPS spectra of C 1s in the fresh and spent samples are shown in Fig. 16 (c). The curves of C 1s region can be deconvoluted into three peaks located at around $284.8 \mathrm{eV}, 286.1 \mathrm{eV}$ and $288.8 \mathrm{eV}$, which can be attributed to $\mathrm{C}-\mathrm{C}$ binding, $\mathrm{C}-\mathrm{O}$ binding, and $\mathrm{C}=\mathrm{O}$ binding ${ }^{52}$. After the adsorption of $\mathrm{Hg}^{0}$, the content of $\mathrm{C}=\mathrm{O}$ groups was decreased from $14.1 \%$ to $6.6 \%$. In contrast, the content of $\mathrm{C}-\mathrm{O}$ groups was increased from $15.5 \%$ to $26.6 \%$. The results indicate that the $\mathrm{C}=\mathrm{O}$ groups might be converted into the $\mathrm{C}-\mathrm{O}$ groups in the process of $\mathrm{Hg}^{0}$ removal. The $\mathrm{C}=\mathrm{O}$ groups could act as the electrons' accepter during the $\mathrm{Hg}^{0}$ oxidization process and facilitate the electron transfer ${ }^{57}$, which could be interpreted as reactions 19 and 20.

$$
\begin{gathered}
\mathrm{Hg}^{0}(\text { ads })--2 \mathrm{e}^{-} \rightarrow \mathrm{Hg}^{2+}(\text { ads }) \\
\mathrm{C}=\mathrm{O}+\mathrm{e}^{-} \rightarrow \mathrm{C}-\mathrm{O}
\end{gathered}
$$



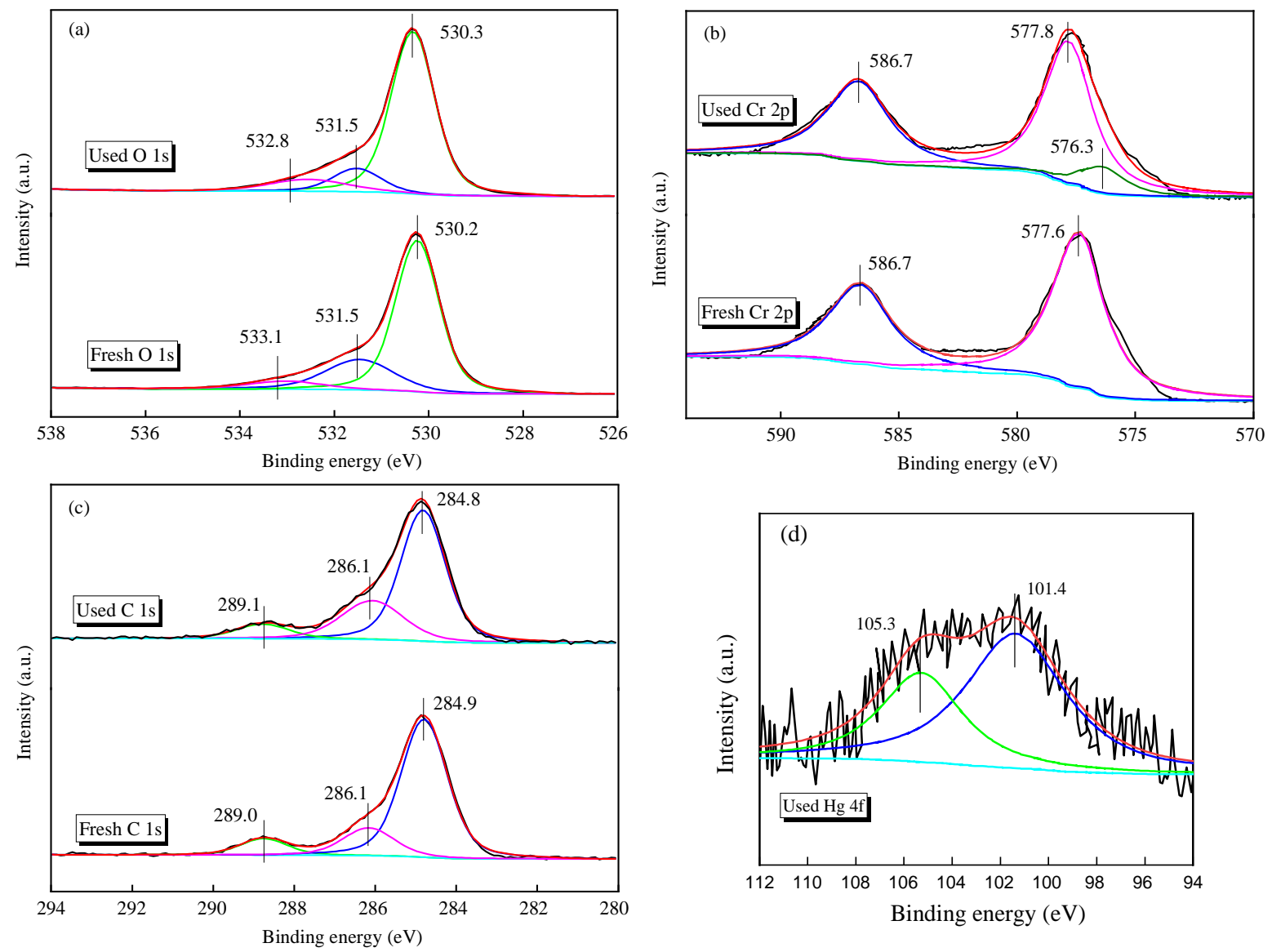

Fig. 16 XPS spectra of fresh and used MIL101-Cr sorbents for O 1s, Cr 2p, C 1s and Hg 4f.

(Reaction condition: $\mathrm{N}_{2}+5 \% \mathrm{O}_{2}, 203 \mu \mathrm{g} / \mathrm{m}^{3}, 8 \times 10^{5} \mathrm{~h}^{-1}, 200{ }^{\circ} \mathrm{C}$ )

Table 2 Surface compositions of the fresh and used sorbents based on XPS results.

\begin{tabular}{|c|c|c|c|c|c|c|c|c|c|c|c|}
\hline & \multicolumn{2}{|l|}{$\mathrm{O} 1 \mathrm{~s}$} & \multicolumn{3}{|c|}{$\mathrm{C} 1 \mathrm{~s}$} & \multicolumn{4}{|c|}{$\mathrm{Cr} 2 \mathrm{p}$} & \multicolumn{2}{|l|}{$\mathrm{Hg} 4 \mathrm{f}$} \\
\hline & $\mathrm{O}^{2-}$ & $\mathrm{O}^{*}$ & $\mathrm{C}-\mathrm{O}$ & C-C & $\mathrm{C}-\mathrm{O}$ & $\mathrm{C}=\mathrm{O}$ & $\mathrm{Cr}^{3+}$ & & $\mathrm{Cr}^{2+}$ & & \\
\hline $\begin{array}{l}\text { Binding energy } \\
\text { (eV) }\end{array}$ & 530.2 & 531.5 & 533.1 & 284.9 & 286.1 & 289.0 & 577.6 & 586.7 & 576.3 & 101.4 & 105.3 \\
\hline $\begin{array}{l}\text { Atomic } \\
\text { concentration } \\
\text { (\%) (fresh) }\end{array}$ & 70.2 & 23.4 & 6.4 & 70.4 & 15.5 & 14.1 & 61.9 & 38.1 & 0 & & \\
\hline $\begin{array}{l}\text { Atomic } \\
\text { concentration } \\
\text { (\%) (used) }\end{array}$ & 77.5 & 10.3 & 12.2 & 67.8 & 26.6 & 6.6 & 55.8 & 37.9 & 6.3 & 65.1 & 34.9 \\
\hline
\end{tabular}

Fig. 16 (d) shows the XPS spectra of $\mathrm{Hg} 4 \mathrm{f}$ for the spent MIL101-Cr sorbent. Two peaks corresponding to $\mathrm{Hg}^{2+}$ at $101.4 \mathrm{eV}$ and $105.3 \mathrm{eV}$ were observed, which indicate that $\mathrm{Hg}^{0}$ is oxidized over the MIL101-Cr sorbent and remained on the surface of sorbent. However, $\mathrm{Hg}^{0}$ could not be 
detected on the surface of the used sorbent, which may be due to the escape of $\mathrm{Hg}^{0}$ from the sample when pretreated under a vacuum before the XPS analysis.

\subsubsection{Adsorption kinetics analysis}

Several kinetic models, such as pseudo-first-order model, intra-particle diffusion equation, pseudosecond-order model and Elovich kinetic equation, had been used to determine the mechanism of the mercury adsorption process ${ }^{58,59}$. The pseudo-second-order model based on the Langmuir-type rate expression has been commonly used to describe the $\mathrm{Hg}^{0}$ chemisorption process ${ }^{57}$, from which the equilibrium adsorption capacity could be calculated as well.

From this study it has already concluded that the $\mathrm{Hg}^{0}$ removal process over the MIL101-Cr sorbent at $200{ }^{\circ} \mathrm{C}$ belongs to chemisorption. Hence, the pseudo-second-order model was used to simulate the adsorption of $\mathrm{Hg}^{0}$ by the MIL101-Cr sample as described by the following Eq. $21^{60}$ :

$$
\frac{\mathrm{dq}}{\mathrm{dt}}=k_{2}\left(\mathrm{q}_{\mathrm{e}}-\mathrm{q}\right)^{2}
$$

With the boundary conditions $\mathrm{t}=0$ to $\mathrm{t}=\mathrm{t}$ and $\mathrm{q}=0$ to $\mathrm{q}=\mathrm{q}_{\mathrm{t}}$, the above equation can be integrated as follows (Eqs. 22-23):

$$
\begin{gathered}
\frac{\mathrm{t}}{\mathrm{q}_{\mathrm{t}}}=\frac{1}{k_{2} \mathrm{q}_{\mathrm{e}}^{2}}+\frac{1}{\mathrm{q}_{\mathrm{e}}} \mathrm{t} \\
\mathrm{q}_{\mathrm{t}}=\frac{\mathrm{t}}{\left(1 / k_{2} \mathrm{q}_{\mathrm{e}}^{2}\right)+\left(\mathrm{t} / \mathrm{q}_{\mathrm{e}}\right)}
\end{gathered}
$$

Where $\mathrm{q}_{\mathrm{t}}$ and $\mathrm{q}_{\mathrm{e}}$ represent the amount of $\mathrm{Hg}^{0}(\mu \mathrm{g} / \mathrm{g})$ adsorbed at time $\mathrm{t}$ and equilibrium, respectively. $\mathrm{k}_{2}$ represents the adsorption reaction rate constant of the pseudo-second-order sorption $(\mathrm{g} /(\mu \mathrm{g} \cdot \min ))$. The values of $\mathrm{k}_{2}$ and $\mathrm{q}_{\mathrm{e}}$ could be obtained by fitting the $\mathrm{Hg}^{0}$ adsorption curve. The accumulative $\mathrm{Hg}^{0}$ adsorption capacity and model fitting results of MIL101-Cr at different temperatures are shown in Fig. 17. The correspond kinetic parameters $\left(\mathrm{q}_{\mathrm{e}}, \mathrm{k}_{2}\right)$ and correlation coefficient $\left(\mathrm{R}^{2}\right)$ for the MIL101-Cr 
sorbent at different temperatures are listed in Table 3. The results indicate that the correlation coefficient $\left(\mathrm{R}^{2}\right)$ for the MIL101-Cr sorbent were greater than 0.999 at different adsorption temperatures. As it can be observed in Fig. 17, the pseudo-second-order model could fit the experimental data very well. This demonstrates that the pseudo-second-order model could be used to well describe the $\mathrm{Hg}^{0}$ adsorption on the MIL101-Cr sorbent. The equilibrium adsorption capacity calculated for the sorbent amounted to $25656 \mu \mathrm{g} / \mathrm{g}$ at $200{ }^{\circ} \mathrm{C}$, which is much higher than those of the commercial activated carbon ${ }^{57}$ and other sorbents investigated by previous studies ${ }^{38,57,59}$ (Table 1). Therefore, it can be concluded that the MIL101-Cr sorbent has great potential to be used as a promising $\mathrm{Hg}^{0}$ removal sorbent.

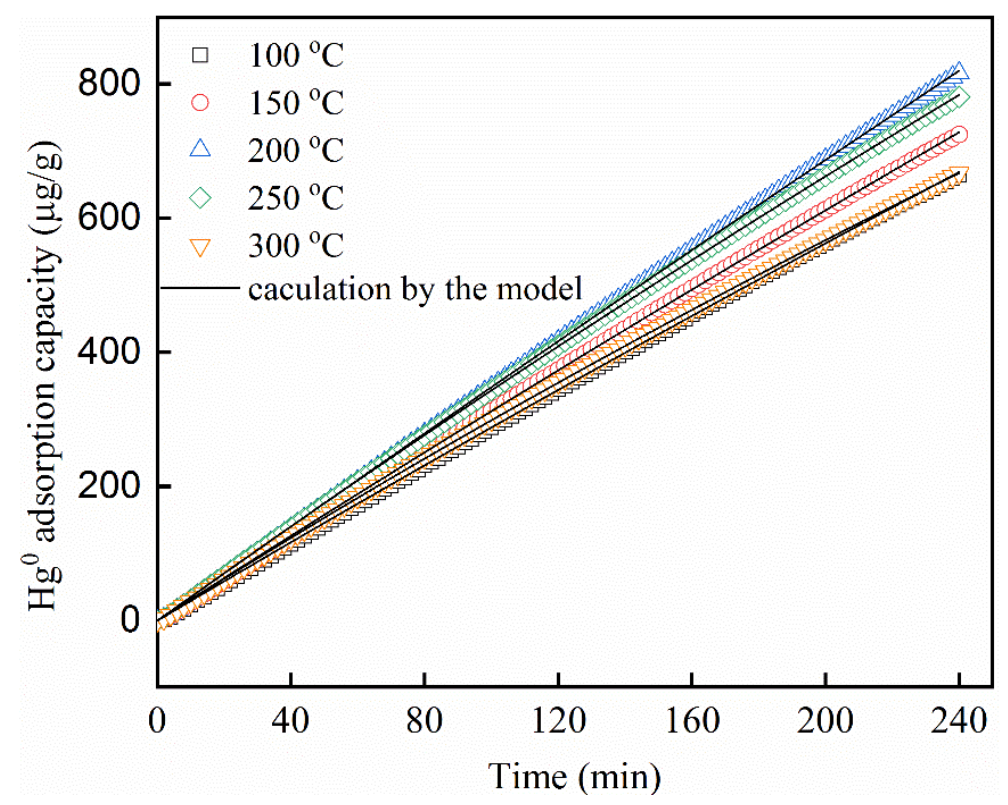

Fig. 17 Simulation of $\mathrm{Hg}^{0}$ adsorption on MIL101-Cr by the pseudo-second-order model (Reaction condition: $\mathrm{N}_{2}+5 \% \mathrm{O}_{2}, 203 \mu \mathrm{g} / \mathrm{m}^{3}, 8 \times 10^{5} \mathrm{~h}^{-1}, 200{ }^{\circ} \mathrm{C}$ )

Table 3 The kinetic parameters of the pseudo-second-order model for the MIL101-Cr sorbent.

\begin{tabular}{llllll}
\hline Temperature $\left({ }^{\circ} \mathrm{C}\right)$ & 100 & 150 & 200 & 250 & 300 \\
\hline $\mathrm{qe}(\mu \mathrm{g} / \mathrm{g})$ & 11853 & 14811 & 25656 & 9398 & 5600 \\
$k_{2} \times 10^{8}(\mathrm{~g} /(\mu \mathrm{g} \cdot \mathrm{min}))$ & 2.1 & 1.5 & 0.54 & 4.0 & 10.1 \\
$R^{2}$ & 0.99986 & 0.99992 & 0.99993 & 0.99994 & 0.99997 \\
\hline
\end{tabular}




\section{Conclusions}

In this study, the MIL101-Cr sorbent was prepared and used to remove $\mathrm{Hg}^{0}$ from the simulated coalfired flue gas. The results showed that the MIL101-Cr sorbent achieved the $\mathrm{Hg}^{0}$ removal efficiency excess of $85 \%$ within $4 \mathrm{~h}$ at $200{ }^{\circ} \mathrm{C}$ with the condition of a relatively high $\mathrm{Hg}^{0}$ inlet concentration and high GHSV. Both the $\mathrm{O}_{2}$ and $\mathrm{NO}$ in the flue gas enhanced the $\mathrm{Hg}^{0}$ removal. The effects of $\mathrm{SO}_{2}$ in the flue gas on the $\mathrm{Hg}^{0}$ removal were more complicated. Without the presence of $\mathrm{O}_{2}$ in the flue gas, the $\mathrm{Hg}^{0}$ adsorption was significantly impaired by $\mathrm{SO}_{2}$, whereas a low concentration of $\mathrm{SO}_{2}$ had a negative effect on the $\mathrm{Hg}^{0}$ removal with the help of $\mathrm{O}_{2}$ in the flue gas. However, a high $\mathrm{SO}_{2}$ content in the flue gas still significantly weakened the $\mathrm{Hg}^{0}$ removal ability even in the presence of $\mathrm{O}_{2}$. The introduction of $\mathrm{O}_{2}$ and $\mathrm{NO}$ to the flue gas could counteract the adverse effect of $\mathrm{SO}_{2}$ on $\mathrm{Hg}^{0}$ adsorption. $\mathrm{H}_{2} \mathrm{O}$ slightly inhibited $\mathrm{Hg}^{0}$ removal performance due to the competitive adsorptions between $\mathrm{H}_{2} \mathrm{O}$ and $\mathrm{Hg}^{0}$. The XPS analysis indicated that the surface $\mathrm{Cr}^{3+}$, oxygen species and $\mathrm{C}=\mathrm{O}$ groups on the surface of the

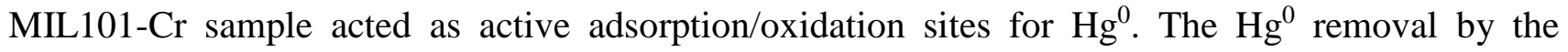
MIL101-Cr sorbent belonged to chemisorption and could be described by pseudo-second-order model. The equilibrium adsorption capacity calculated for the sorbent amounted to $25656 \mu \mathrm{g} \cdot \mathrm{g}^{-1}$ at $200{ }^{\circ} \mathrm{C}$. From the analysis of the experimental results of this study, it can be concluded that the MIL101-Cr sorbent has great potential to be used as a promising $\mathrm{Hg}^{0}$ removal sorbent.

\section{Acknowledgements}

This project was financially supported by the National Key R\&D Program of China (2018YFC1901200, 2016YFB0600604), the National Natural Science Foundation of China (51676040), the Jiangsu Basic Research Program (BK20181281), the Scientific Research Foundation 
of Graduate School of Southeast University (3203009703), and the Postgraduate Research \& Practice Innovation Program of Jiangsu Province (KYCX17_0079). We would also like to acknowledge the financial support from the China Scholarship Council (CSC) which enables the first author (Lu Dong) to complete the part of the reported work at the University of Nottingham under the supervision of the second corresponding author (Hao Liu). 


\section{References}

(1) Xu, W.; Li, T.; Hao, Q.; et al. Effect of Flue Gas Components on Hg0 Oxidation over Fe/HZSM-5 Catalyst. Ind. Eng. Chem. Res. 2015, 54, (1), 146-152.

(2) Jampaiah, D.; Ippolito, S. J.; Sabri, Y. M.; et al. Ceria-zirconia modified MnOx catalysts for gaseous elemental mercury oxidation and adsorption. Catal. Sci. Technol. 2016, 6, 1792-1803.

(3) Zhao, S.; Pudasainee, D.; Duan, Y.; et al. A review on mercury in coal combustion process: Content and occurrence forms in coal, transformation, sampling methods, emission and control technologies. Prog. Energy Combust. Sci. 2019, 73, 26-64.

(4) Zhao, S.; Mei, J.; Xu, H.; et al. Research of mercury removal from sintering flue gas of iron and steel by the open metal site of Mil-101(Cr). J. Hazard. Mater. 2018, $351,301-307$.

(5) Xu, Y.; Deng, F.; Pang, Q.; et al. Development of waste-derived sorbents from biomass and brominated flame retarded plastic for elemental mercury removal from coal-fired flue gas. Chem. Eng. J. 2018, 350, 911-919.

(6) IEA's Coal Report 2018. https://www.iea.org/coal2018/

(7) Zheng, J.; Shah, K. J.; Zhou, J.; et al. Impact of $\mathrm{HCl}$ and $\mathrm{O} 2$ on removal of elemental mercury by heat-treated activated carbon: Integrated X-ray analysis. Fuel Process. Technol. 2017, 167, 11-17. 
(8) Yang, Y.; Huang, Q.; Wang, Q.. Ignoring Emissions of Hg from Coal Ash and Desulfurized Gypsum Will Lead to Ineffective Mercury Control in Coal-Fired Power Plants in China. Environ. Sci. Technol. 2012, 46, (6), 3058-3059.

(9) Zhang, W.; Zhen, G.; Chen, L.; et al. Economic evaluation of health benefits of mercury emission controls for China and the neighboring countries in East Asia. Energy Policy 2017, 106, 579-587.

(10) Yang, W.; Liu, Z.; Xu, W.; et al. Removal of elemental mercury from flue gas using sargassum chars modified by NH4Br reagent. Fuel 2018, 214, 196-206.

(11) Yang, J.; Ma, S.; Zhao, Y.; et al. Elemental Mercury Removal from Flue Gas over TiO2 Catalyst in an Internal-Illuminated Honeycomb Photoreactor. Ind. Eng. Chem. Res. 2018, 57, (51), 17348-17355.

(12) Zhao, Y.; Yang, J.; Ma, S.; et al. Emission controls of mercury and other trace elements during coal combustion in China: a review. Int. Geol. Rev. 2018, 60, (5-6), 638-670.

(13) Sjostrom, S.; Durham, M.; Bustard, C. J.; et al. Activated carbon injection for mercury control: Overview. Fuel 2010, 89, (6), 1320-1322.

(14) Hsi, H.-C.; Tsai, C.-Y.; Kuo, T.-H.; et al. Development of low-concentration mercury adsorbents from biohydrogen-generation agricultural residues using sulfur impregnation. Bioresour. Technol. 2011, 102, (16), 7470-7477. 
(15) Zhao, B.; Yi, H.; Tang, X.; et al. Copper modified activated coke for mercury removal from coal-fired flue gas. Chem. Eng. J. Chem. Eng. J. 2016, 286, 585-593.

(16) Zhao, H.; Fan, H.; Yang, G.; et al. Integrated Dynamic and Steady State Method and Its Application on the Screening of MoS2 Nanosheet-Containing Adsorbents for Hg0 Capture. Energy Fuels 2018, 32, (4), 5338-5344.

(17) Liu, H.; Zhao, Y.; Zhou, Y.; et al. Removal of gaseous elemental mercury by modified diatomite. Sci. Total Environ. 2019, 652, 651-659.

(18) Li, H.; Zhu, W.; Yang, J.; et al. Sulfur abundant S/FeS2 for efficient removal of mercury from coal-fired power plants. Fuel 2018, 232, 476-484.

(19) Li, H.; Zhu, L.; Wu, S.; et al. Synergy of $\mathrm{CuO}$ and $\mathrm{CeO} 2$ combination for mercury oxidation under low-temperature selective catalytic reduction atmosphere. Int. J. Coal Geol. 2017, 170, 69-76.

(20) Yang, J.; Zhao, Y.; Zhang, S.; et al. Mercury removal from flue gas by magnetospheres present in fly ash: Role of iron species and modification by HF. Fuel Process. Technol. 2017, 167, 263-270.

(21) Yang, J.; Zhao, Y.; Zhang, J.; et al. Regenerable Cobalt Oxide Loaded Magnetosphere Catalyst from Fly Ash for Mercury Removal in Coal Combustion Flue Gas. Environ. Sci. Technol. 2014, 48, (24), 14837-14843. 
(22) Yang, J.; Zhu, W.; et al. Selenium Functionalized Metal-Organic Framework MIL-101 for Efficient and Permanent Sequestration of Mercury. Environ. Sci. Technol. 2019, 53, (4), 2260-2268.

(23) Zhang, W.; Yan, Z.; Gao, J.; et al. Metal-organic framework UiO-66 modified magnetite@silica core-shell magnetic microspheres for magnetic solid-phase extraction of domoic acid from shellfish samples. J. Chromatogr. A 2015, 1400, 10-18.

(24) Yang, Y.; Ma, X.; Feng, F.; et al. Magnetic solid-phase extraction of triclosan using core-shell Fe3O4@MIL-100 magnetic nanoparticles, and its determination by HPLC with UV detection. Microchim. Acta 2016, 183, (8), 2467-2472.

(25) Shi, Z.; Xu, C.; Guan, H.; et al. Magnetic metal organic frameworks (MOFs) composite for removal of lead and malachite green in wastewater. Colloids Surf., A $2018,539,382-390$.

(26) Sun, X.; Gao, G.; Yan, D.; et al. Synthesis and electrochemical properties of Fe3O4@MOF core-shell microspheres as an anode for lithium ion battery application. Appl. Surf. Sci. 2017, 405, 52-59.

(27) Qasem, N. A. A.; Ben-Mansour, R.; Habib, M. A.. An efficient CO2 adsorptive storage using MOF-5 and MOF-177. Appl. Energy 2018, 210, 317-326.

(28) Zhang, X.; Shen, B.; Zhu, S.; et al. UiO-66 and its Br-modified derivates for elemental mercury removal. J. Hazard. Mater. 2016, 320, 556-563. 
(29) Chen, D.; Zhao, S.; Qu, Z.; et al. Cu-BTC as a novel material for elemental mercury removal from sintering gas. Fuel 2018, 217, 297-305.

(30) Zhang, X.; Shen, B.; Shen, F.; et al. The behavior of the manganese-cerium loaded metal-organic framework in elemental mercury and NO removal from flue gas. Chem. Eng. J. 2017, 326, 551-560.

(31) Granite, E. J.; Pennline, H. W.; Hargis, R. A.. Novel Sorbents for Mercury Removal from Flue Gas. Ind. Eng. Chem. Res. 2000, 39, (4), 1020-1029.

(32) Chen, G.; Zhang, D.; Zhang, A.; et al. CrOx-MnOx-TiO2 adsorbent with high resistance to $\mathrm{SO} 2$ poisoning for $\mathrm{Hg} 0$ removal at low temperature. J. Ind. Eng. Chem. 2017, 55, 119-127.

(33) Wang, S.; Zhang, Q.; Zhang, G.; et al. Effects of sintering flue gas properties on simultaneous removal of SO2 and NO by ammonia-Fe(II)EDTA absorption. J. Energy Inst. 2017, 90, (4), 522-527.

(34) Yan, N.; Chen, W.; Chen, J.; et al. Significance of RuO2 Modified SCR Catalyst for Elemental Mercury Oxidation in Coal-fired Flue Gas. Environ. Sci. Technol. 2011, 45, (13), 5725-5730.

(35) Bromberg, L.; Diao, Y.; Wu, H.; et al. Chromium(III) Terephthalate Metal Organic Framework (MIL-101): HF-Free Synthesis, Structure, Polyoxometalate Composites, and Catalytic Properties. Chem. Mater. 2012, 24, (9), 1664-1675. 
(36) Yang, C.; Yan, X.. Metal-Organic Framework MIL-101(Cr) for HighPerformance Liquid Chromatographic Separation of Substituted Aromatics. Anal. Chem. 2011, 83, (18), 7144-7150.

(37) Wang, T.; Wu, J.; Zhang, Y.; et al. Increasing the chlorine active sites in the micropores of biochar for improved mercury adsorption. Fuel 2018, 229, 60-67.

(38) Cai, J.; Shen, B.; Li, Z.; et al. Removal of elemental mercury by clays impregnated with KI and KBr. Chem. Eng. J. 2014, 241, 19-27.

(39) Yang, J.; Zhao, Y.; Liang, S.; et al. Magnetic iron-manganese binary oxide supported on carbon nanofiber ( $\mathrm{Fe} 3-\mathrm{xMnxO} 4 \mathrm{CNF})$ for efficient removal of $\mathrm{Hg} 0$ from coal combustion flue gas. Chem. Eng. J. 2018, 334, 216-224.

(40) Tan, Z.; Su, S.; Qiu, J.; et al. Preparation and characterization of Fe2O3-SiO2 composite and its effect on elemental mercury removal. Chem. Eng. J. 2012, 195-196, 218-225.

(41) Dong, L.; Xie, J.; Fan, G.; et al. Experimental and theoretical analysis of element mercury adsorption on Fe3O4/Ag composites. Korean J. Chem. Eng. 2017, 34, (11), 2861-2869.

(42) Li, H.; Wu, C.; Li, Y.; et al. Superior activity of MnOx-CeO2/TiO2 catalyst for catalytic oxidation of elemental mercury at low flue gas temperatures. Appl. Catal., B 2012, 111-112, 381-388. 
(43) Yang, W.; Liu, Y.; Wang, Q.; et al. Removal of elemental mercury from flue gas using wheat straw chars modified by Mn-Ce mixed oxides with ultrasonic-assisted impregnation. Chem. Eng. J. 2017, 326, 169-181.

(44) Xu, W.; Adewuyi, Y. G.; Liu, Y.; et al. Removal of elemental mercury from flue gas using $\mathrm{CuOx}$ and $\mathrm{CeO} 2$ modified rice straw chars enhanced by ultrasound. Fuel Process. Technol. 2018, 170, 21-31.

(45) Li, Y.; Murphy, P. D.; Wu, C.; et al. Development of Silica/Vanadia/Titania Catalysts for Removal of Elemental Mercury from Coal-Combustion Flue Gas. Environ. Sci. Technol. 2008, 42, (14), 5304-5309.

(46) Yang, J.; Zhu, W.; Zhang, S.; et al. Role of flue gas components in Hg0 oxidation over $\mathrm{La} 0.8 \mathrm{Ce} 0.2 \mathrm{MnO} 3$ perovskite catalyst in coal combustion flue gas. Chem. Eng. J. 2019, 360, 1656-1666.

(47) Wu, H.; Li, C.; Zhao, L.; et al. Removal of Gaseous Elemental Mercury by Cylindrical Activated Coke Loaded with $\mathrm{CoOx}-\mathrm{CeO} 2$ from Simulated Coal Combustion Flue Gas. Energy Fuels 2015, 29, (10), 6747-6757.

(48) Li, Y.; Murphy, P.; Wu, C.. Removal of elemental mercury from simulated coalcombustion flue gas using a SiO2-TiO2 nanocomposite. Fuel Process. Technol. 2008, $89,(6), 567-573$.

(49) Xie, Y.; Li, C.; Zhao, L.; et al. Experimental study on $\mathrm{Hg} 0$ removal from flue gas over columnar MnOx-CeO2/activated coke. Appl. Surf. Sci. 2015, 333, 59-67. 
(50) Pang, L.; Yang, P.; Yang, H.; et al. Application of Fe3O4@MIL-100 (Fe) coreshell magnetic microspheres for evaluating the sorption of organophosphate esters to dissolved organic matter (DOM). Sci. Total Environ. 2018, 626, 42-47.

(51) Tang, Q., X.; Zhang, Y.; Zhong, Wei.; et al. Fe3O4 and metal-organic framework MIL-101(Fe) composites catalyze luminol chemiluminescence for sensitively sensing hydrogen peroxide and glucose. Talanta 2018, 179, 43-50.

(52) Yang, J.; Zhao, Y.; Ma, S.; et al. Mercury Removal by Magnetic Biochar Derived from Simultaneous Activation and Magnetization of Sawdust. Environ. Sci. Technol. 2016, 50, (21), 12040-12047.

(53) Xu, Y.; Luo, G.; Pang, Q.; et al. Adsorption and catalytic oxidation of elemental mercury over regenerable magnetic Fe-Ce mixed oxides modified by non-thermal plasma treatment. Chem. Eng. J. 2019, 358, 1454-1463.

(54) Zhang, C.; Song, W.; Zhang, X.; et al. Synthesis and evaluation of activated carbon spheres with copper modification for gaseous elemental mercury removal. $J$. Porous Mater. 2018.

(55) Shen, B.; Tian, L.; Li, F.; et al. Elemental mercury removal by the modified biochar from waste tea. Fuel 2017, 187, 189-196.

(56) Li, X.; Cao, J.; Zhang, W.. Stoichiometry of Cr(VI) Immobilization Using Nanoscale Zerovalent Iron (nZVI): A Study with High-Resolution X-Ray Photoelectron Spectroscopy (HR-XPS). Ind. Eng. Chem. Res. 2008, 47, (7), 2131-2139. 
(57) Xu, Y.; Luo, G.; He, S.; et al. Efficient removal of elemental mercury by magnetic chlorinated biochars derived from co-pyrolysis of Fe(NO3)3-laden wood and polyvinyl chloride waste. Fuel 2019, 239, 982-990.

(58) Skodras, G.; Diamantopoulou, I.; Pantoleontos, G.; et al. Kinetic studies of elemental mercury adsorption in activated carbon fixed bed reactor. J. Hazard. Mater. 2008, 158, (1), 1-13.

(59) Li, G.; Wang, S.; Wu, Q.; et al. Mechanism identification of temperature influence on mercury adsorption capacity of different halides modified bio-chars. Chem. Eng. J. 2017, 315, 251-261.

(60) Cáceres, L.; Escudey, M.; Fuentes, E.; et al. Modeling the sorption kinetic of metsulfuron-methyl on Andisols and Ultisols volcanic ash-derived soils: Kinetics parameters and solute transport mechanisms. J. Hazard. Mater. 2010, 179, (1), 795 803. 